
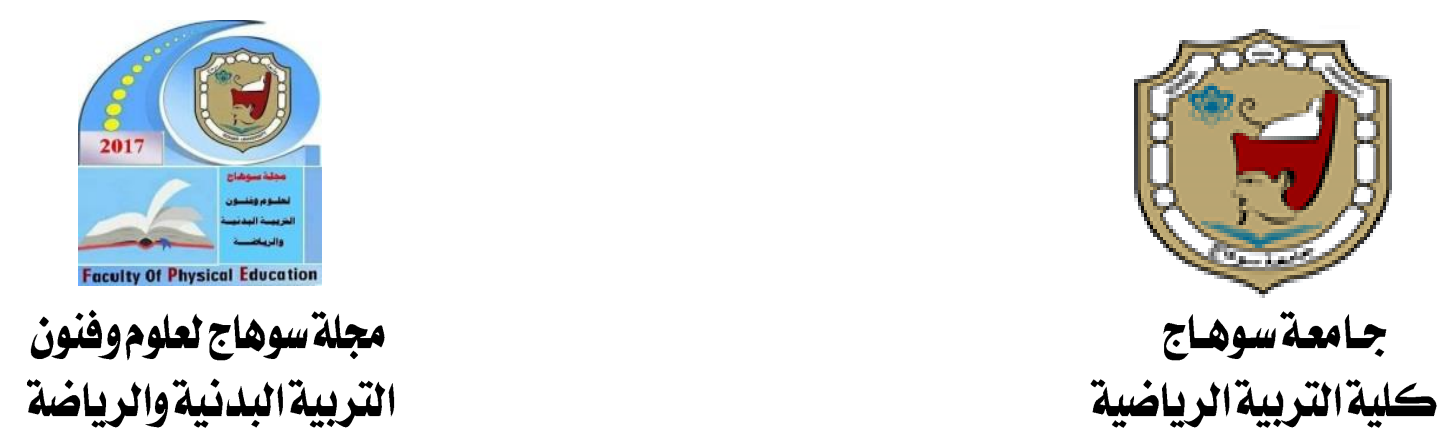

تأثير استخدام إستراتيجية الياءاتا الخهس (5E's) على عاداتالعقل وتعلم بعض المهاراتالحركية في الكرة/الطائرة للى تلميلاتالمرحلة الإعدادية

\author{
أ.م.د / فايزة محمد شبل رزف \\ أستاذ مساعد بتسم الألماب الجماعية والعاب المضرب

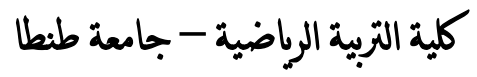

أ.م.د /شعبان حلمى حافظ محمد

استاذ مساعد بتسم المنامج وتدريس التربية الرياضية

كلية التببة الراضية- جامعة سوهاج

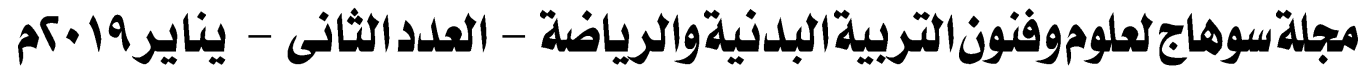
الترقيم الدولى : 2682-3748) print (ISSN 2682-3837) (ISSN 2682) 
تأثير استخدام إستراتيجية الياءات الخمس (5E's)على عادات العقل وتعلم بعض المهارات الحركية في الكرة

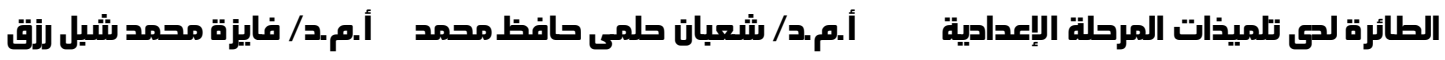

تأثير استخدام إستراتيجية الياءاتا الخمس (5E's) على عادات العقل وتعلم بعض المهارات

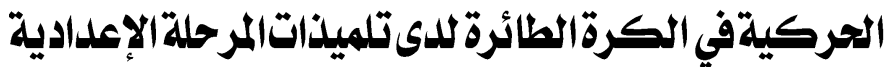

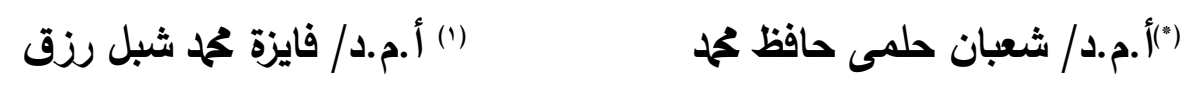

المقلمةومشكالة|البحث :

يتميز العصر الحالي بالتطور العلمي السريع، الذي يحتم على المتعلمين إمتلاك مقومات

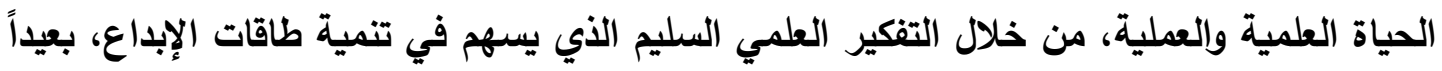

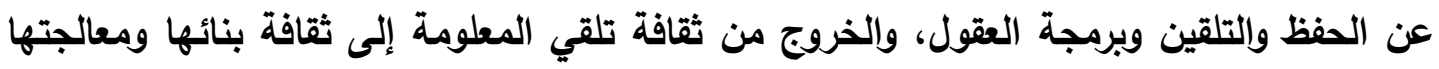

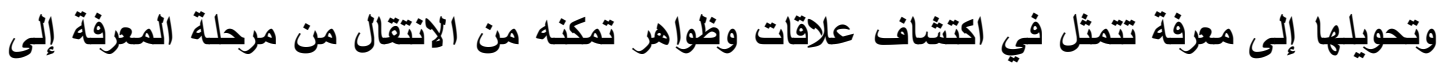

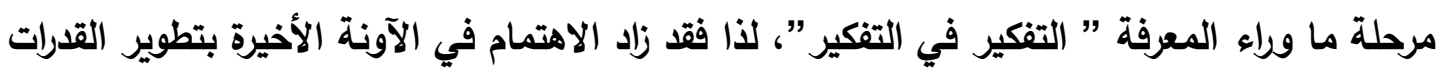
العقلية للمتعلمين، وتنمية تفكيرهم وإعدادهم ليكونوا قادرين على الابتكار والتجديد. وشه الفكر التربوي في العنوات الأخيرة تحولات تربوية مهمة، وإنتقادات كبيرة لطرق

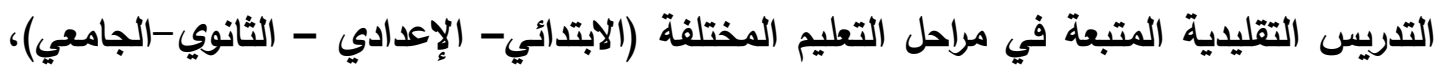
ومن جملة هذه التحولات الإهتمام المتزايد بتنمية التفكير لاى الطلاب.

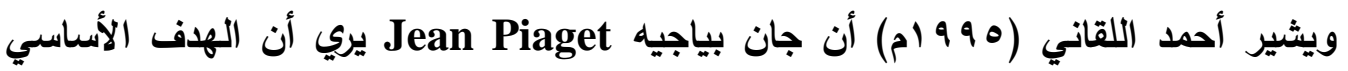

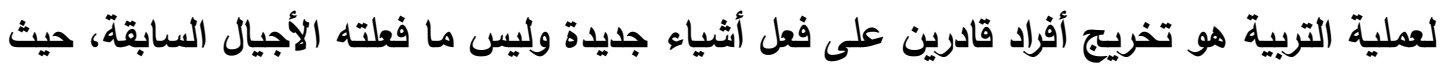

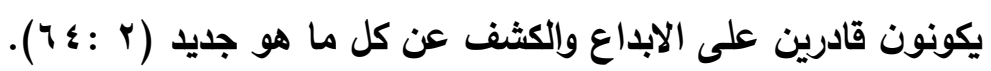

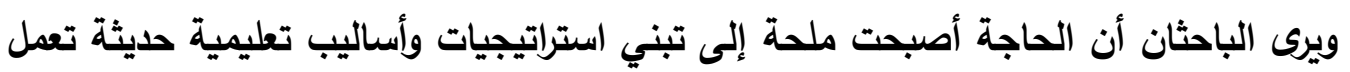

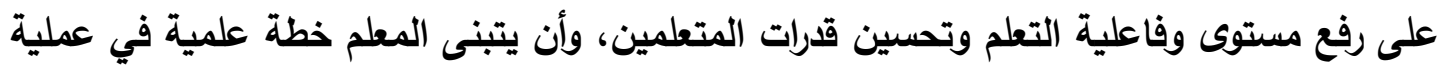

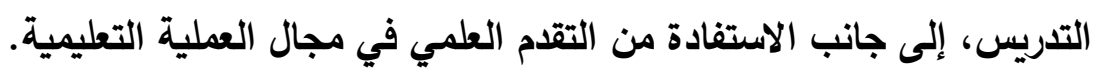

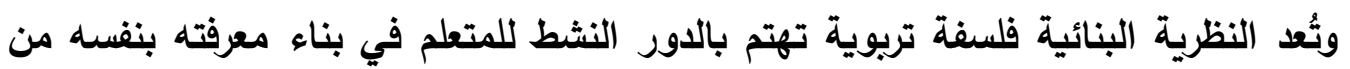

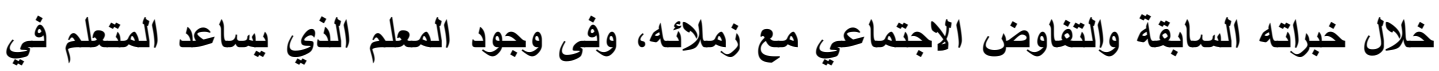

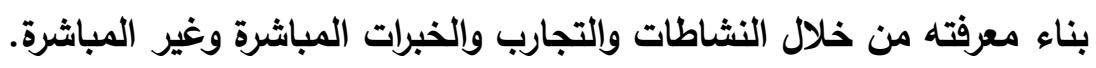

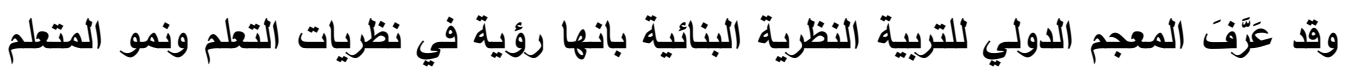

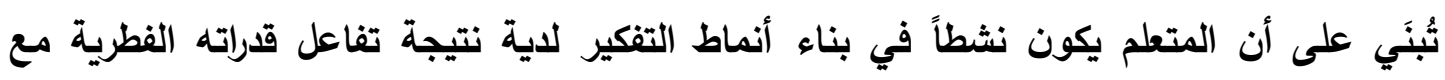

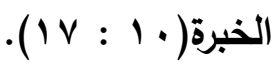

\footnotetext{
(*)(استاذ مساعد بقسم المناهج وتدريس التربية الرياضية -كلية التربية الرياضية- جامعة سوهاج

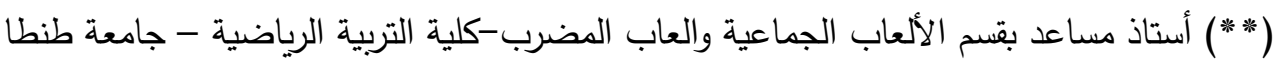


ويثير كمال زيتون (r . . . أن أصحاب هذه النظرية يروا أن عملية اكتساب المعرفة تعتبر

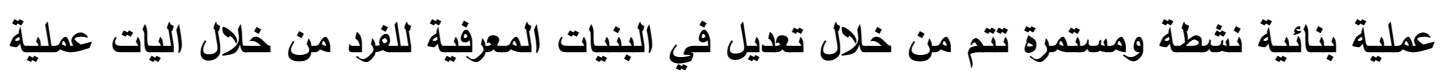

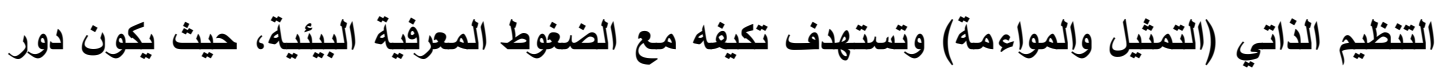

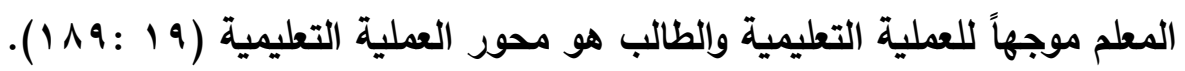

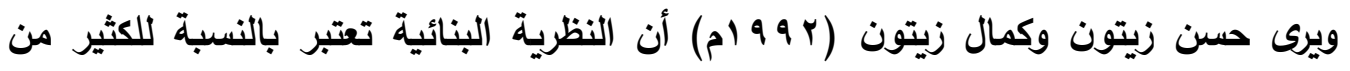

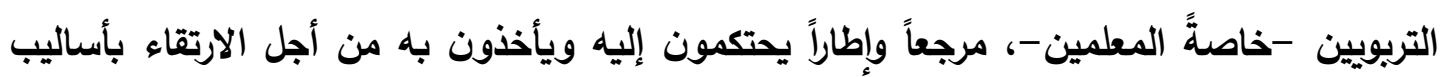

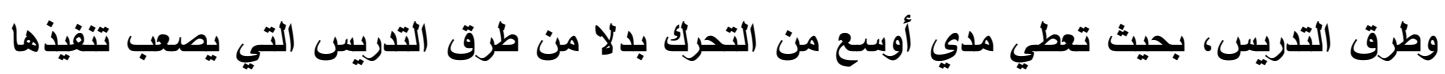

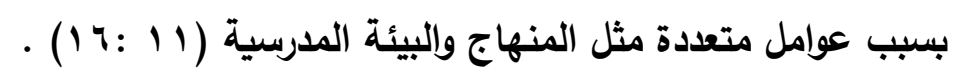

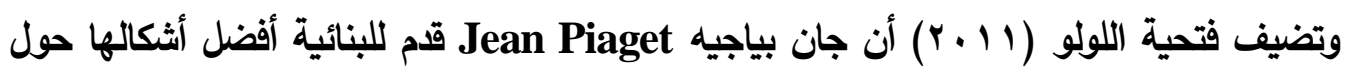

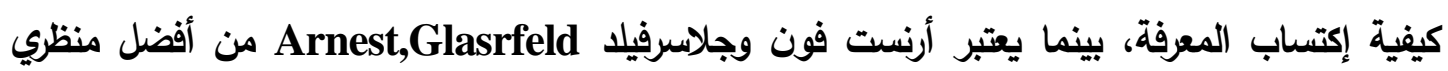

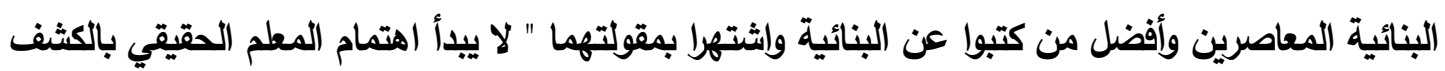

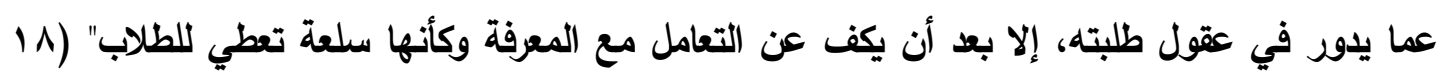
.$(0$ :

ولما كان التعلم البنائي يعتمد على فكرة أن الطالب يبني معرفته بنفسه، لذا لم يعد المعلم

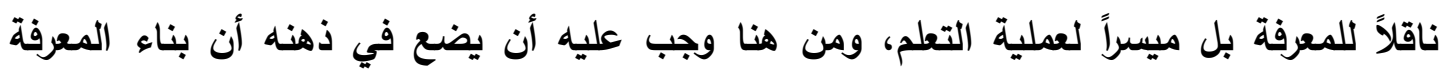

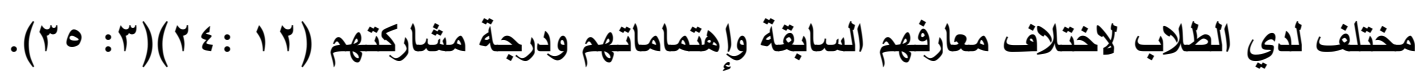
وقد إنبثق من النظرية البنائية مجموعة من استراتيجيات التدريس منها:

ا بـ دورة التعلم

r. ب. ب. بورة التعلم المعدلة. (4Es)

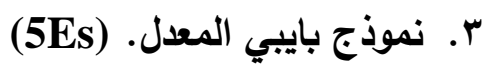

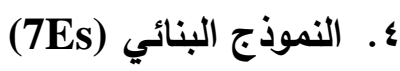
ه. ـ نموذج التعلم المتمركز حول المشكلة.

T.

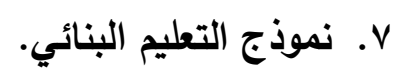

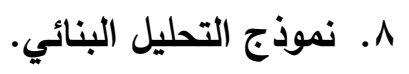

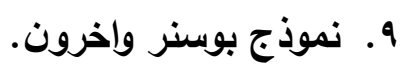

ـ 1. استراتيجية الاحداث المتناقضة.

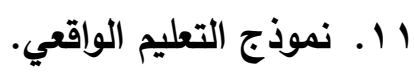

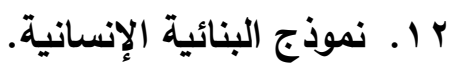


تأثير استخدام إستراتيجية الياءات الخمس (5E's)على عادات العقل وتعلم بعض المهارات الحركية في الكرة

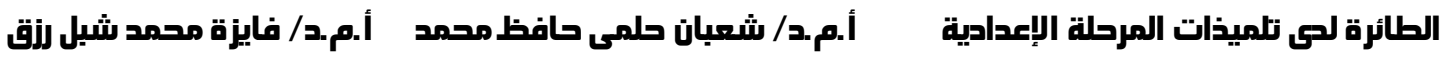

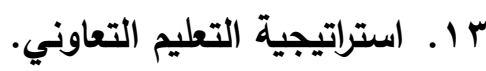

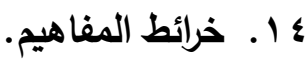

ه 1 ـ استراتيجية المتثابهات والمعايير التشابهية.

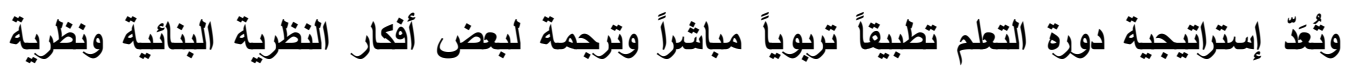

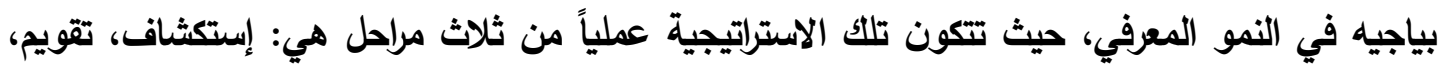
تطبيق.

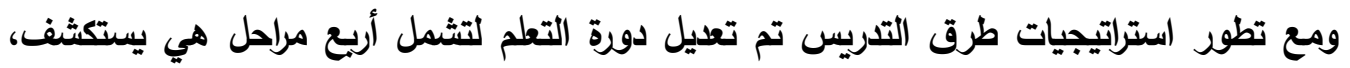

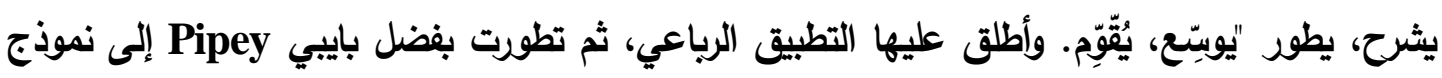
الياءات الخمس (5Es) لتشمل خمس مراحل هي: يثارك، يستكشف، يشرح، يطور "يوسع"، يُقَّقَّم.

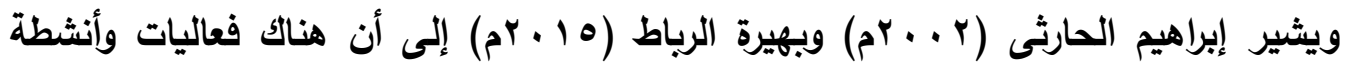

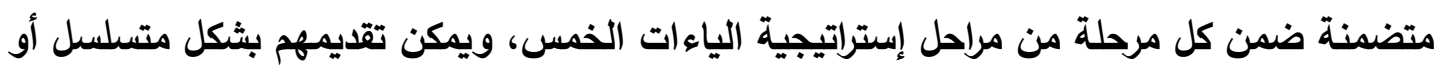

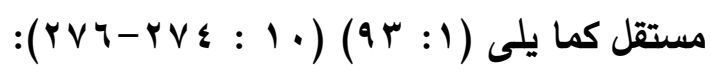
الياء الأولى : يشاركك أو ينخرط (Engage) وفى هذه المرحلة يقوم المعلم بإثارة تفكير التلاميذ ويثجعهم على طرح الأسئلة ومحاولة التعريف بالمشكلة، وينخرط التلاميذ فى التفكير فى الحلول للإجابة عن هذه الأسئلة. الياءألثانية: يستكشف (Explore) فى هذه المرحلة تتاح للتلاميذ فرصة الإندماج فى ممارسة الأنثطة المختلفة، ويطورون

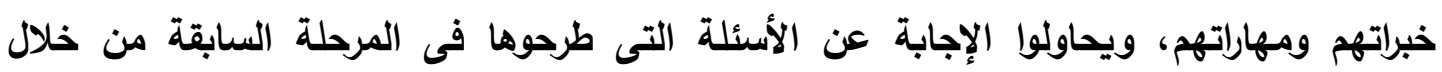

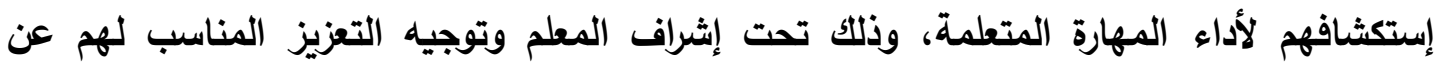
الأداء.

الياءالثالثة: يشرح(Explain) وفى هذه المرحلة يتم مساعدة التلاميذ لثرح المعلومات والمهارات التى إكتثفوها، فعند العمل فى مجموعات نجد التلاميذ يدعمون فهم بعضهم البعض من خلماعل خلال تسجيلهم لأفكارهم وآرائهم، ويتوصلون من خلال شرح المعلم للأداء الصحيح للمهارة بأجزائها المختلفة.

اليائالرابعة: يطور (Elaborate)

في هذه المرحلة يتم السماح للتلاميذ بممارسة المهارات والخبرات الجديدة المتعلمة، ويحصلون

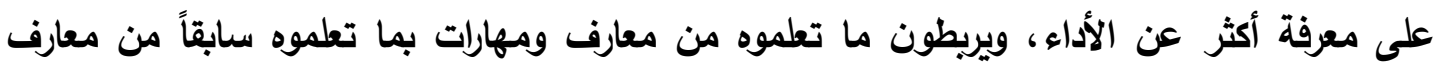
ومهارات ذات الصلة، وذلك بتخطيط واعٍ من المعلم. 
اليائا الخامسلة: يُقَمَّم (Evaluate)

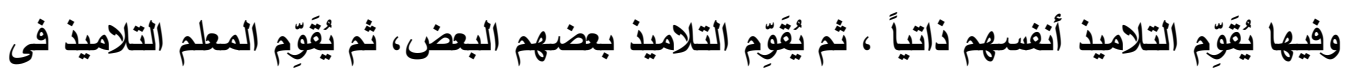

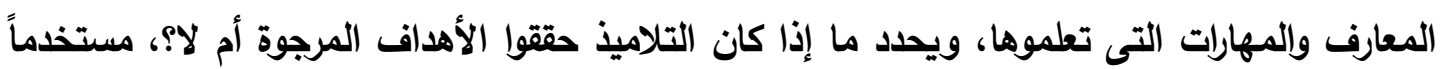

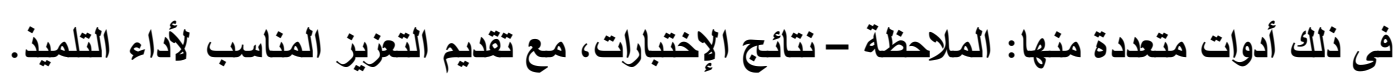

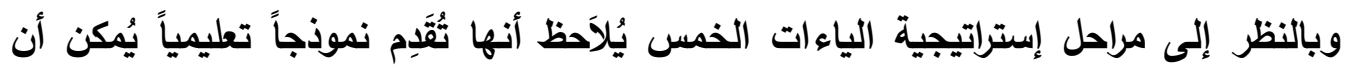

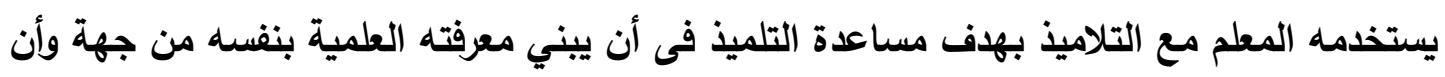
ينمي مفاهيمه وعملياته المعرفية ومهاراته من جهة أخري.

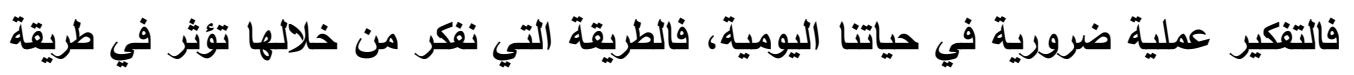

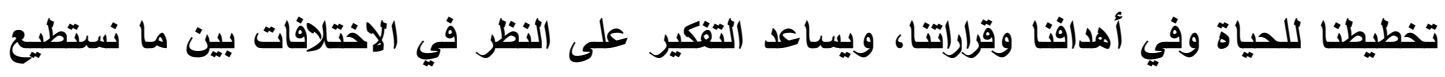

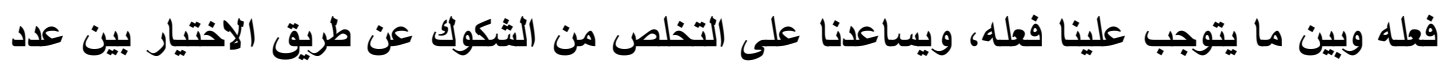

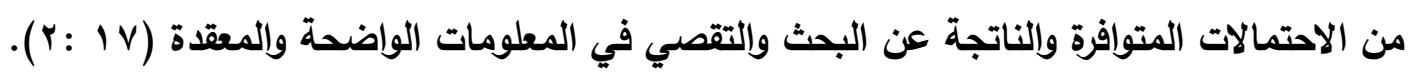

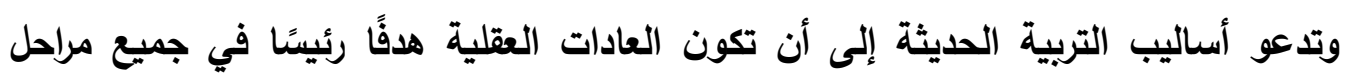

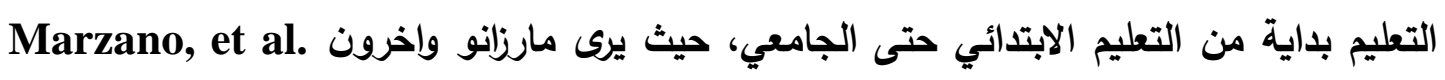

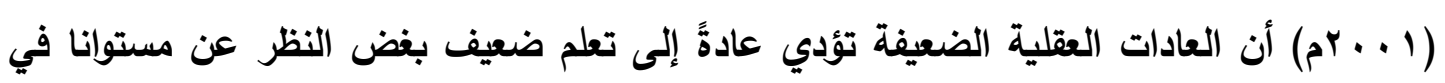

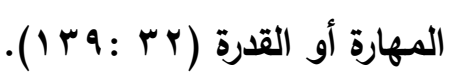

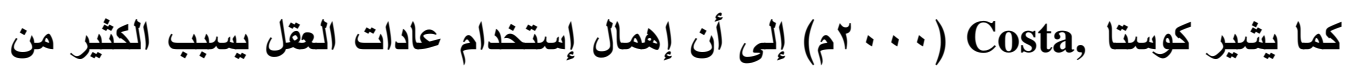

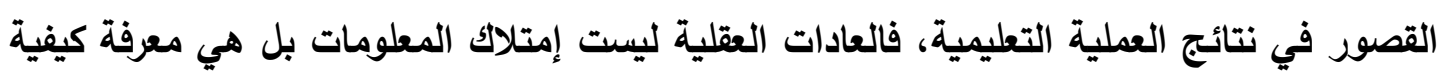

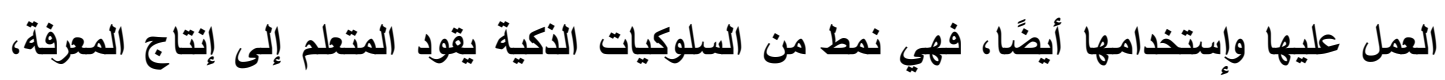

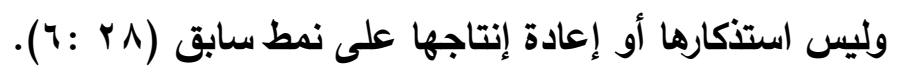

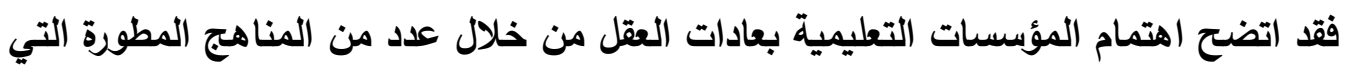

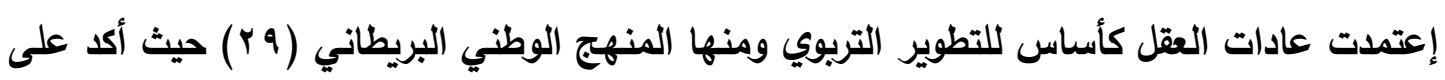

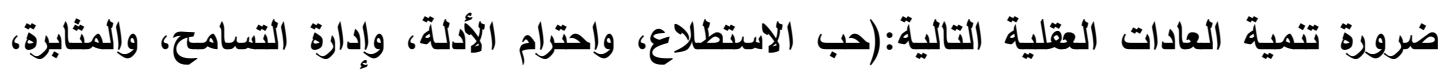

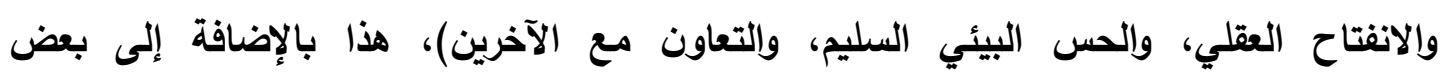

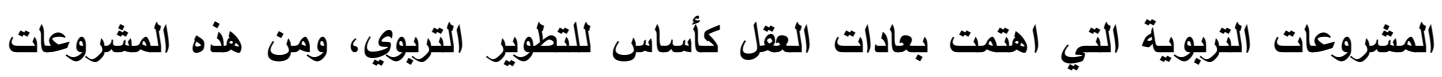

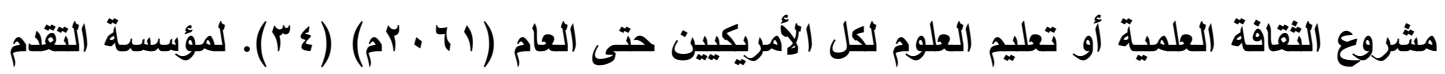

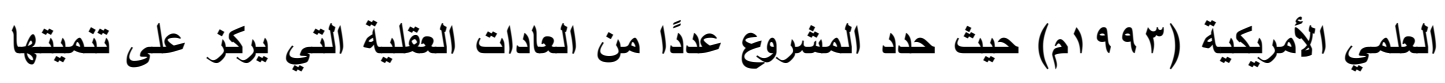

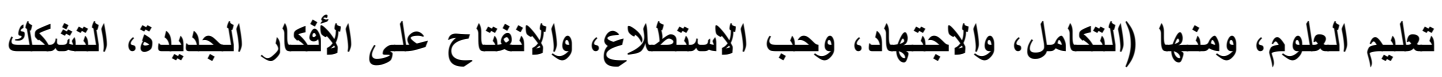

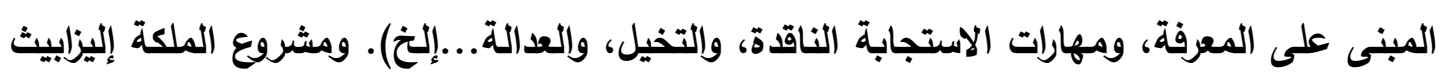
Elizabeth queen project 
تأثير استخدام إستراتيجية الياءات الخمس (5E's)على عادات العقل وتعلم بعض المهارات الحركية في الكرة

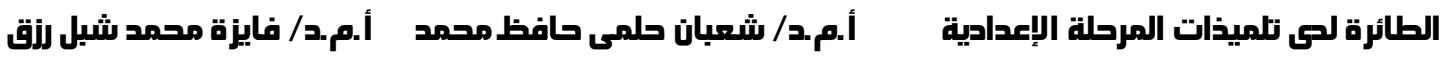

على ضرورة تنمية العادات العقلية التالية (التفكير المرن، والاستماع إلى الآخرين، والسعي للدقة، والإصراد (المثابرة)، والفضول والمتعة في حل المشكلات، ورؤية الموقف بطريقة غير تقليدية) من المناديه خلال المناهج المطورة.

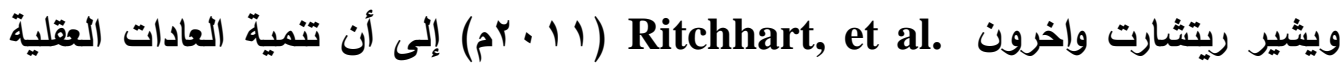
تتطلب من المعلمين استخام أساليب تدريسية تساعد على تجسيد الأفكار لاستيعابها، كما أنها

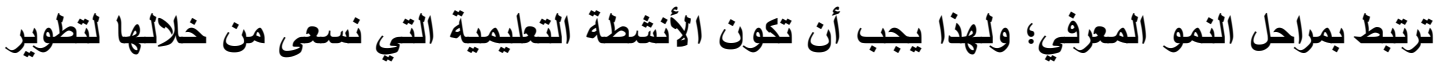

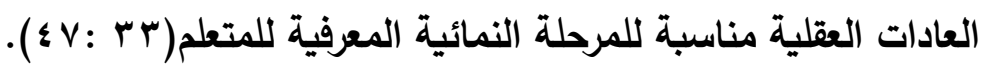

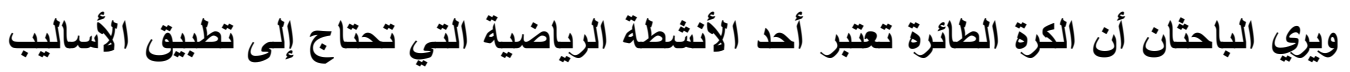

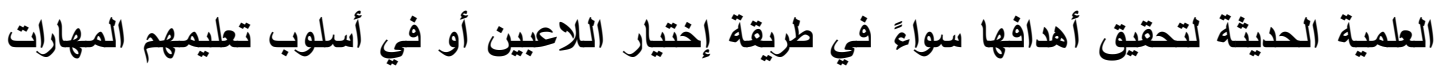

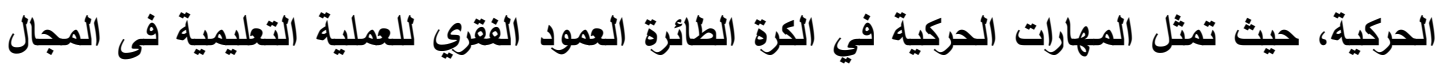

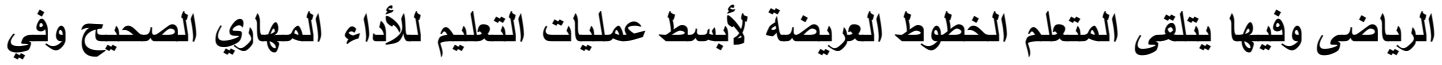
مسارها العصبي الذي يستمر معله طوال فترة حياته. ولاحظ الباحثان في حدود علمهما ومن خلال الاطلاع على الثبكة العالمية للمعلومات(الانترنت)

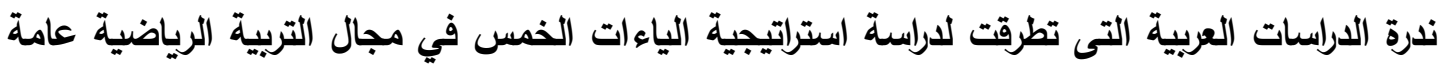
وفى مجال الكرة الطائرة خاصة وربطها بعادات العقل، وان اغلب الدراسات التي تناولت استراتيجية

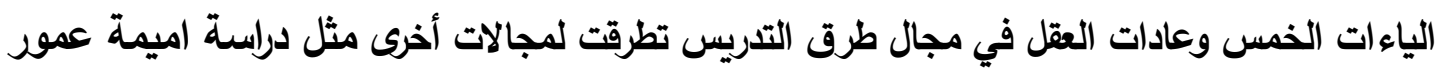

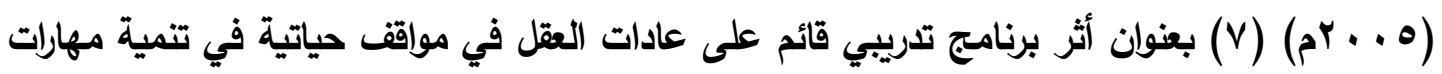

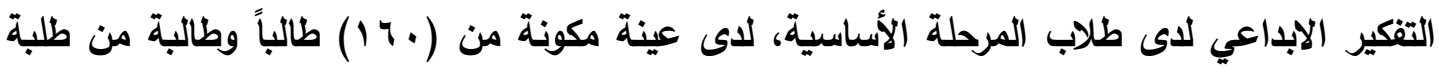

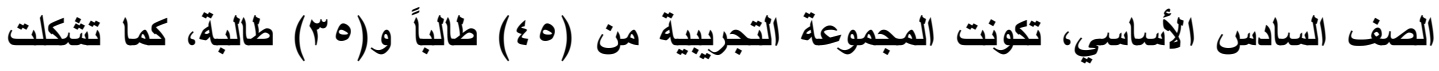

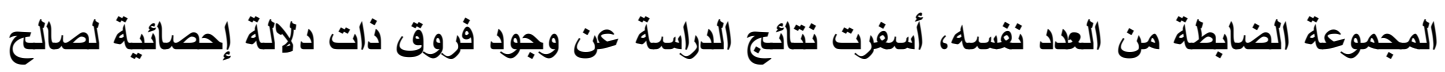

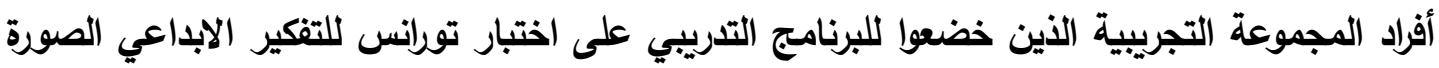

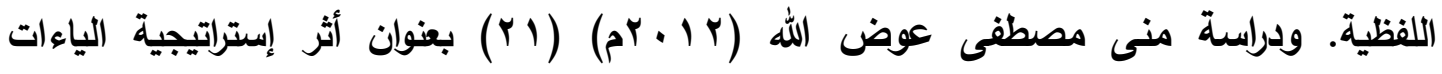

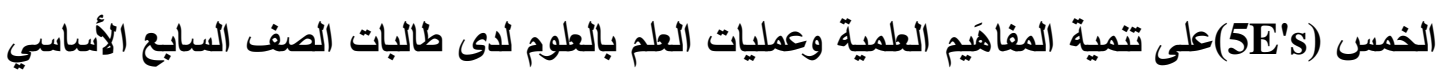

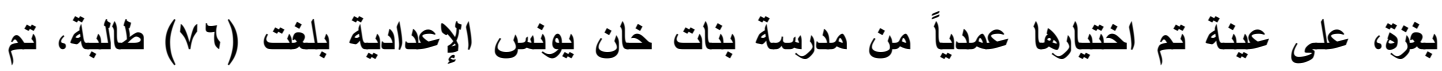

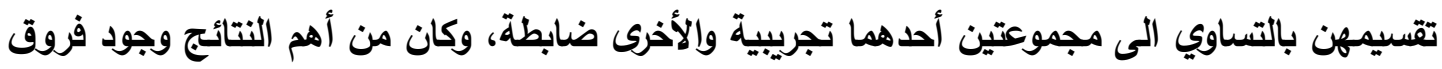

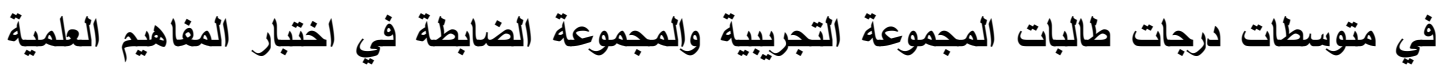

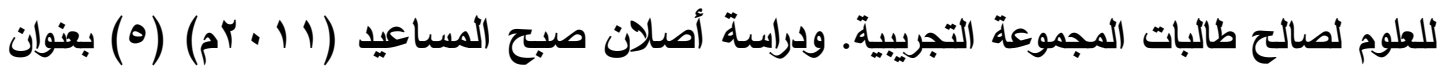

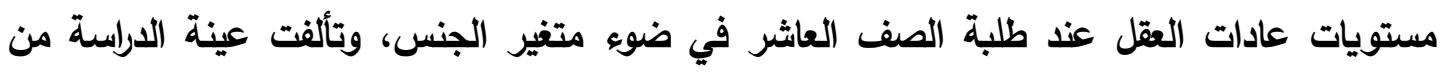

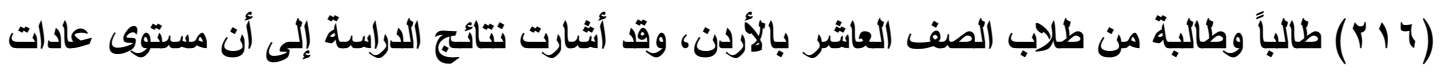


العقل لاى الطلاب(ذكور وإناث) أعلى من الوسط الفرضي، كذلك أشارت النتائج إلى أن الذكور لايهز

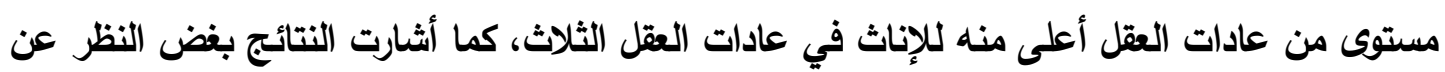

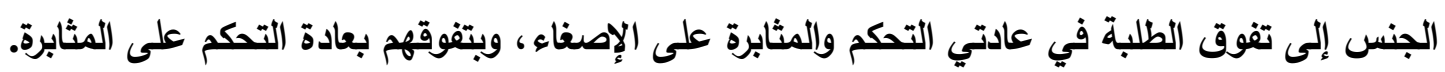

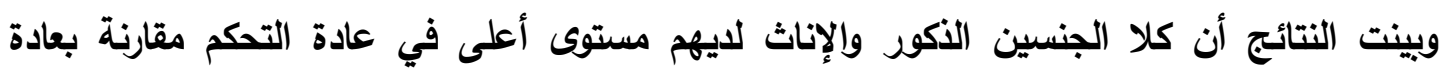

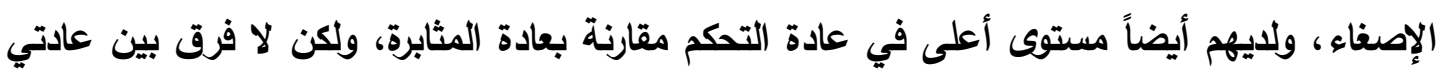

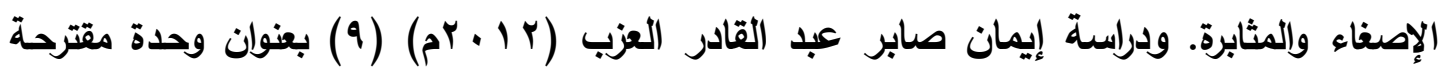

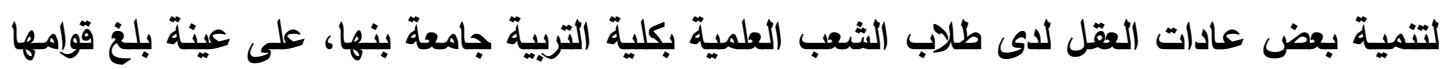

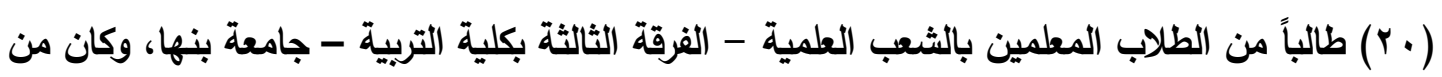

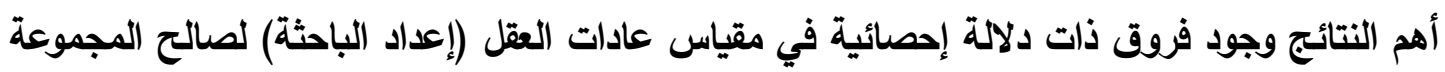

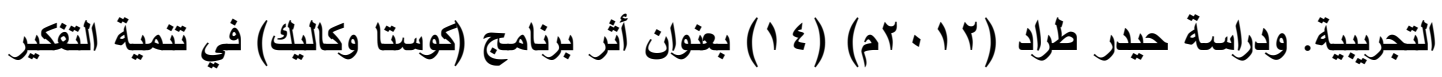

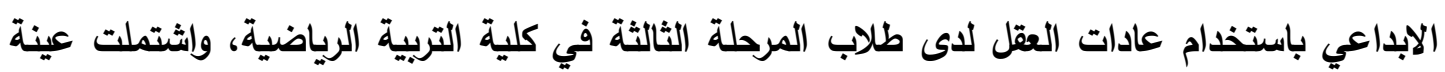

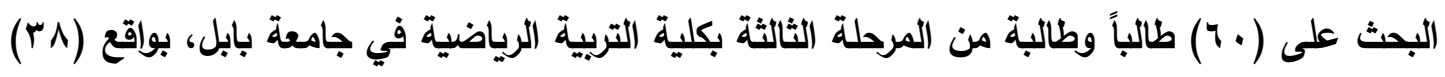

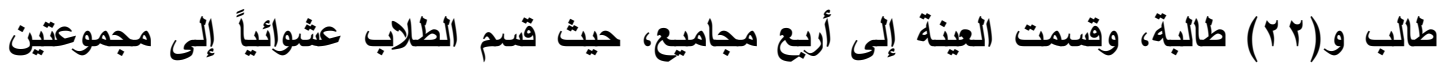

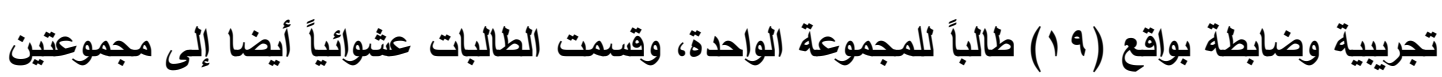

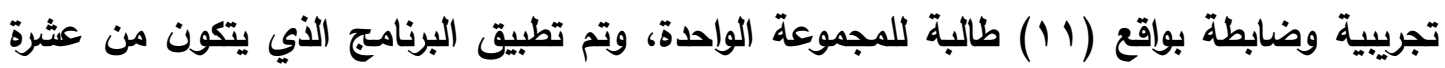

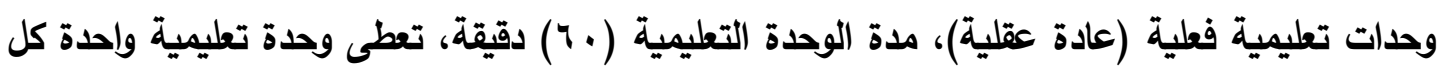

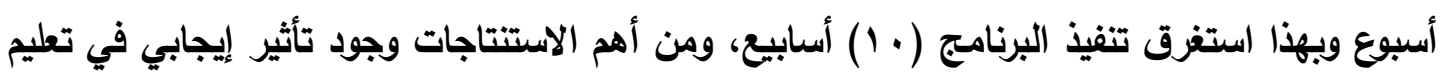

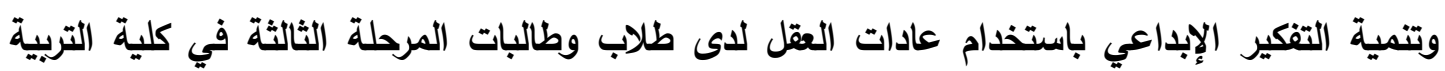

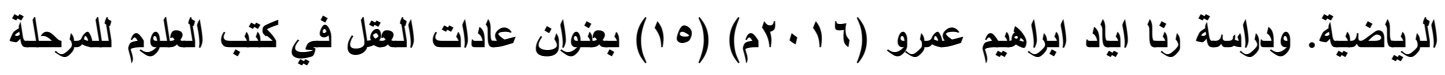

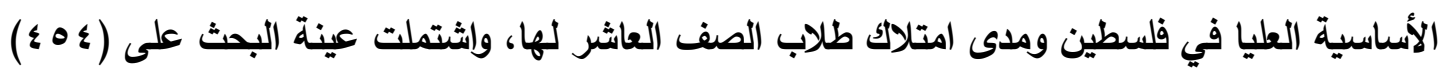

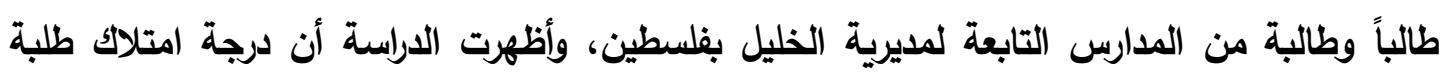

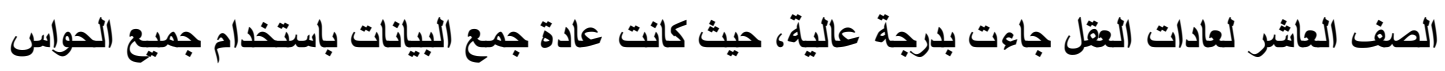

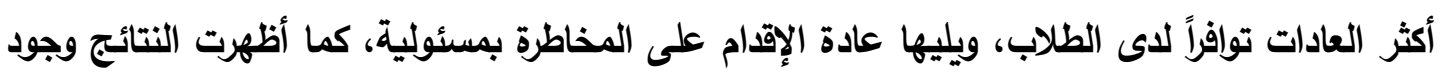

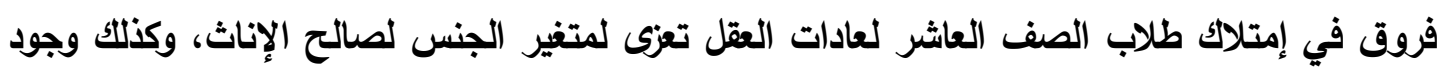

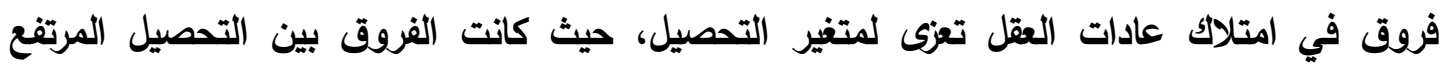

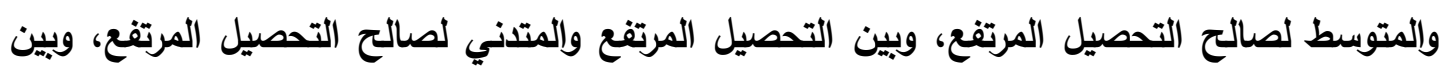

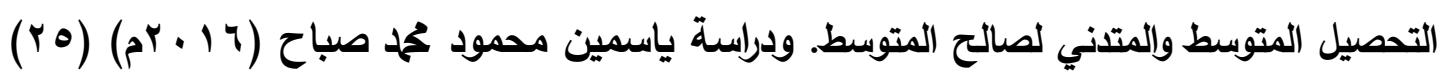

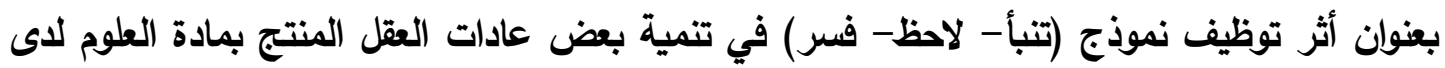

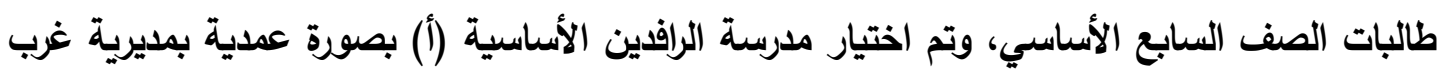


تأثير استخدام إستراتيجية الياءات الخمس (5E's)على عادات العقل وتعلم بعض المهارات الحركية في الكرة

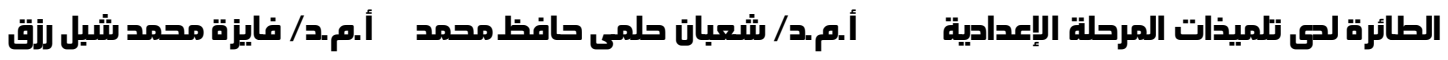

غزة، وتم اختيار شعبتين بصورة عشوائية بسيطة، إحداهما ضابطة بلفت ( ؟ ؛) طالبة، والأخرى تجريبية

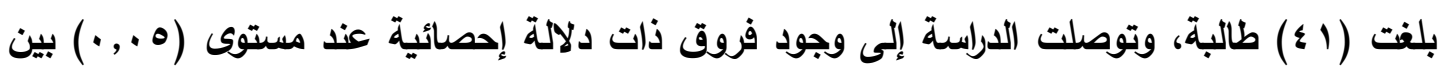

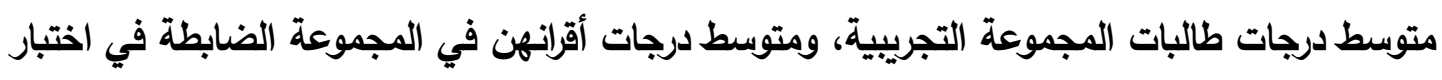

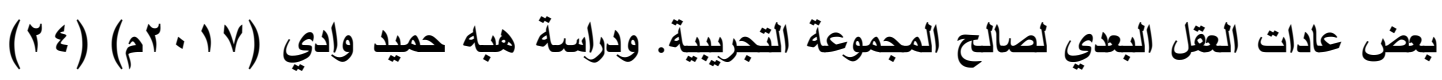

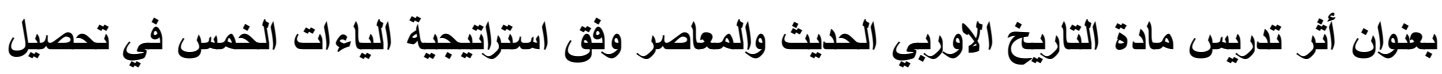

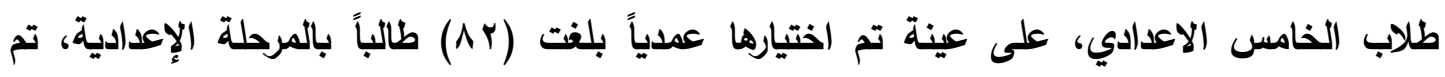

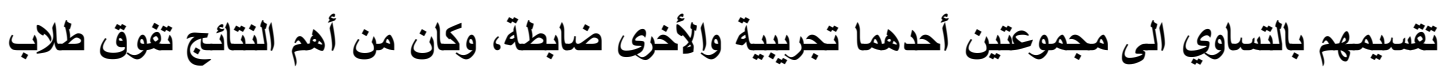

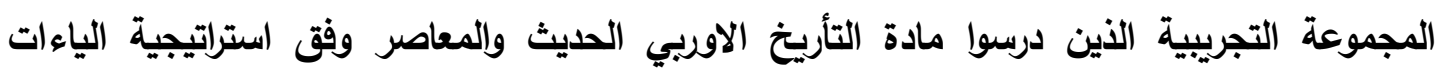
الخمسة على طلاب المجموعة الضابطة الذين درسوا المادة نفسها بالطريقة الاعتيادية في الاختبار التحصيلي.

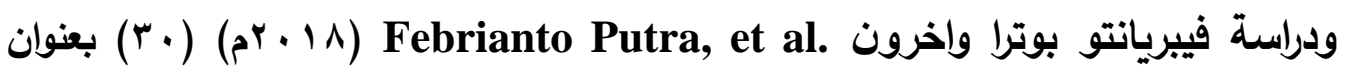

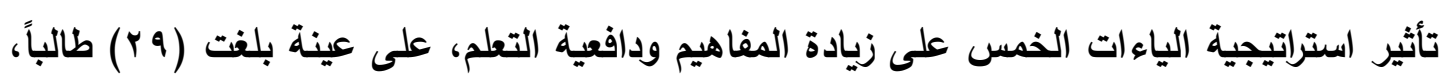

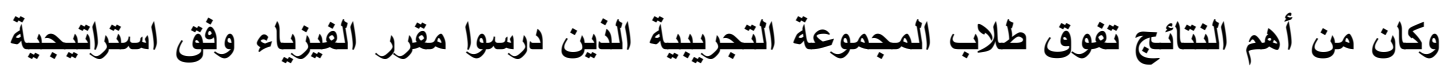
الياءات الخمس في زيادة المفاهيم ودافعية التعلم.

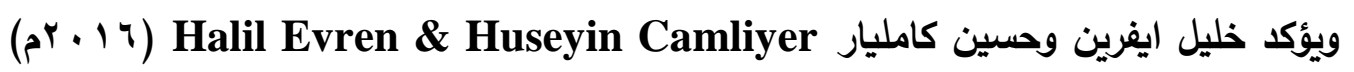

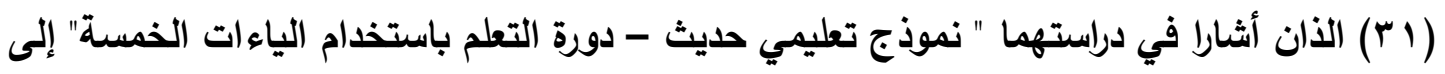

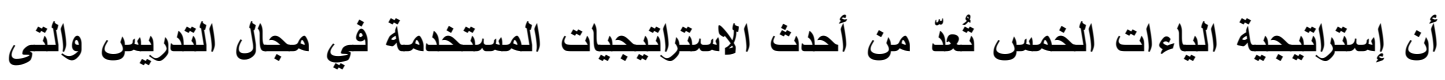
ينبغى تضمينها فى تدريس برامج التربية الرياضية المدرسية. ومن خلال إشراف الباحثان على طلاب وطالبات التربية العملية ببعض البعابة المدارس الإعدادية،

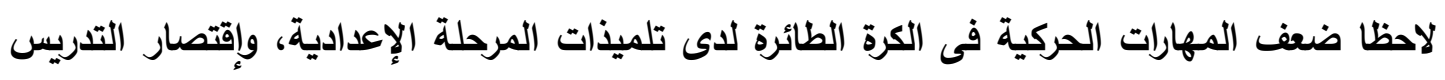

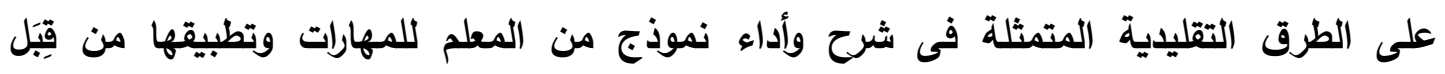

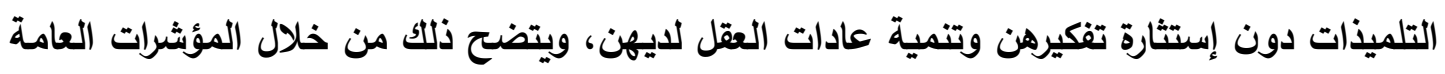

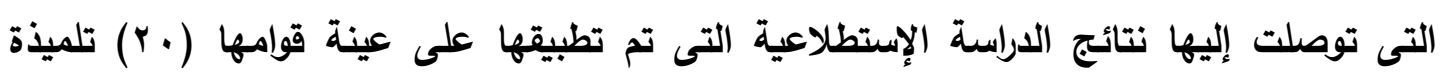

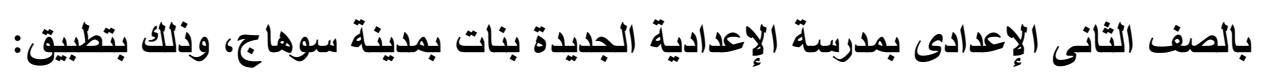

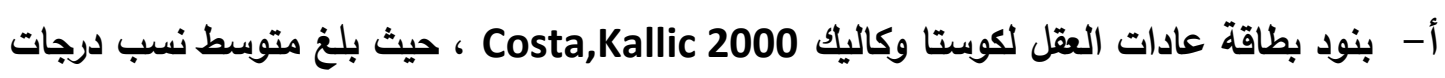

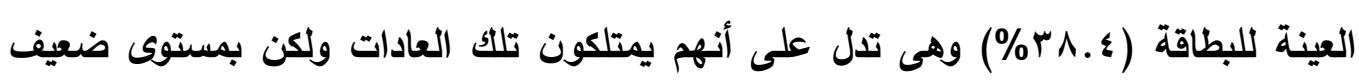

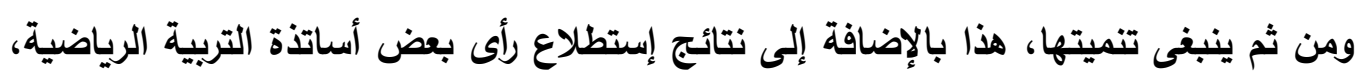

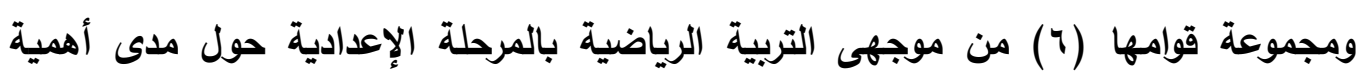
عادات العقل للتلاميذ، والتى أقرت جميعها بأهمية تلك العادات العقلية. 
ب- اختبار المهارات الحركية فى الكرة الطائرة، حيث بلغت نسبة درجات العينة (7 . ؛ \%))، وهى تدل

على ضعف المهارات الحركية لرياضة الكرة الطائرة لايهه ومن ثم ينبغى تنميتها.

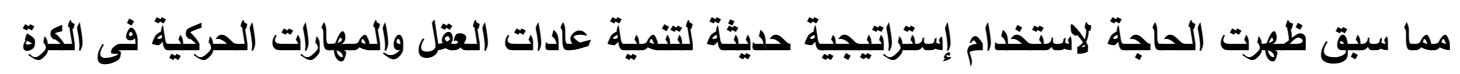

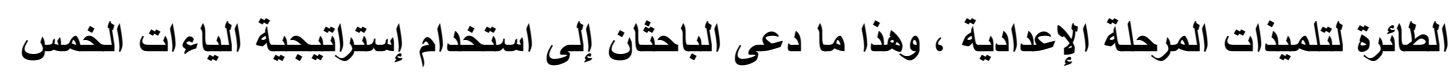
لتنمية عادات العقل وبعض المهارات الحركية فى الكرة الطائرة لاى تلميذات المرحلة الإعدادية. أهمية|لبحث: أهميه عادات تتمثل أهمية البحث الحالي في الآتي: ا - يأتي هذا البحث استجابة لما يطالب به التربويون من ضرورة الاهتمام بتنمية عادات العقل بما يسهم فى تحسين نتائج العملية التعليمية للمتعلمين. r - يأتي هذا البحث استجابةً لما ينادى بـه التربويون من ضرئ لمرورة الاعتمـاد على إستراتيجيات حديثة فى التدريس. ب- قـ يلقى هذا البحث الضوء على أهمية إجراء بحوث أخرى تعتمد على استخدام إستراتيجية الياءات الخمس فى تدريس التربية الرياضية بمراحل التعليم المختلفة. هلدفالبحث:

يهذف البحث الحالي إلى: التعرف على تأثير استخدام استراتيجية الياءات الخمس على عادات العقل وتعلم بعض المهارات الحركية في الكرة الطائرة -قيد البحث- لادى تلميذات المرحلة الإعدادية. حلدود البحث:

1- اقتصرت تجربة البحث على عينة من تلميذات الصف الثاني الإعدادي بمدينة سوهاج

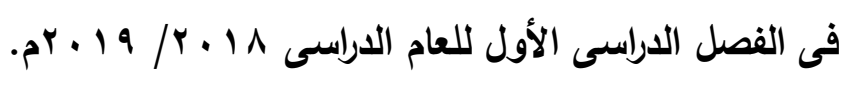

r - - اقتصر قياس تأثير استخدام إستراتيجية الياءات الخمس على عادات الات العقل التالية: (المثابرة، التحكم بالاندفاع، التصور والابداع والابتكار، الاصغاء بفهم وتعاطف، التفكير فوق المعرفي، تحري الدقة، التسـاؤل وحـل المشكلات، التفكيـر التبـادلي أو الجمـاعي، التفكير بمرونة، تطبيق المعارف السابقة في مواقف جليدة، التفكير والتواصل بوضوح ودقة). r- - اقتصر قياس تأثر استخدام إستراتيجية الياءات الخمس على المهارات الحركية التالية

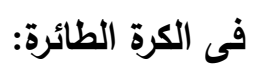
- الإرسال من أسفل أمامى مواجه.

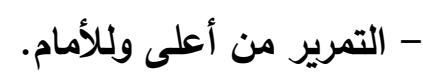
- التمرير من أسفل. 
تأثير استخدام إستراتيجية الياءات الخمس (5E's)على عادات العقل وتعلم بعض المهارات الحركية في الكرة

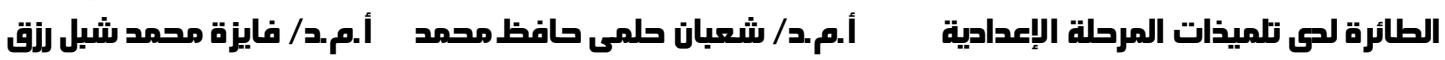

\section{فروض البحث:}

يحاول البحث الحالى التحقق من صحة الفروض التالية: ا. يوجد فرق دال إحصائياً عند مستوى (ه . . ) بين متوسطى القياسين القبلي والبعدي للمجموعة التجريبية في عادات العقل لصالح القياس البعدي. r. يوجد فرق دال إحصائياً عند مستوى (ه ... بين متوسطى القياسين القبلي والبعدي للمجموعة الضابطة في عادات العقل لصالح القياس البعدي. r. يوجد فرق دال إحصائياً عند مستوى (ه...) بين متوسطى القياسين البعديين للمجموعتين التجريبية والضابطة في عادات العقل لصالح المجموعة التجريبية. ء. يوجد فرق دال إحصائياً عند مستوى (0. . ·) بين متوسطى القياسين القبلي والبعدي للمجموعة التجريبية في تعلم بعض المهارات الحركية في الكرة الطائرة لصالح القياس البعدي. ه. يوجد فرق دال إحصائياً عند مستوى (ه ...) بين متوسطى القياسين القبلي والبعدي للمجموعة الضابطة في تعلم بعض المهارات الحركية في الكرة الطائرة لصالح القياس البعدي. \. يوجد فرق دال إحصائياً عند مستوى (ه ...) بين متوسطى القياسين البعديين للمجموعتين التجريبية والضابطة في تعلم بعض المهارات الحركية في الكرة الطائرة لصالح المجموعة التجريبية. مصطلحاتالبحث: البجم:

Thinking التقكير نشاط عقلي وشكل من أثكال العمليات المعرفية التي تستخدم الإدراك والمفاهيم والرموز والتصورات، وأحد الوظائف الأساسية للذكاء والقدرات والاستعدادات ( ع ^ ^ ). (5E's) استراتيجية اليائات الخمسات واحس هي مجموعة فعاليات تعليمية بنائية يتم تنفيذها وفقاً لخمس خطوات متتابعة يمارس فيها المتعلم دوراً إيجابياً أثناء المواقف التعليمية من خلال التفاعل النشط بين المعلم والمتعلم، وخطوات هذه الاستراتيجية هي يثارك، يستكشف، يشرح، يطور، يُقَّومِم.

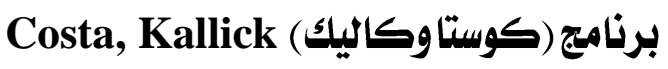
برنامج حديث لتعليم التفكير الابداعي باستخدام عادات العقل، ويتكون من (7 آم ) جلسة كل جلسة تتناول عادة من العادات العقلية الستة عشر، ويساعد البرنامج في تطوير القدرات الإبداعية للمتعلمين ومساعدتهم على التفكير بثكل يُمكِنهم من التصدي للمشكلات التي تواجههم، والعمل على حلها حلاً إبداعياً ( ب : 9 ج). 
عاداتالعقل Thinking Habits

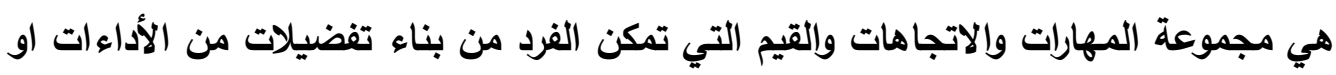

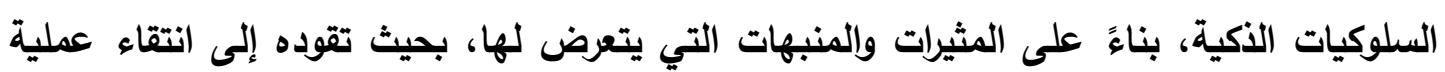

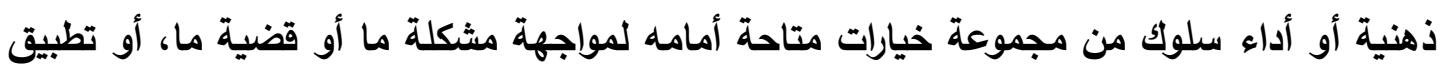

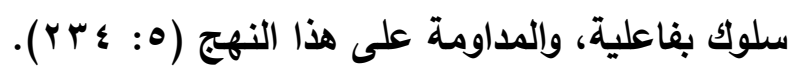

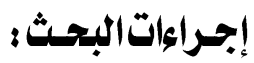

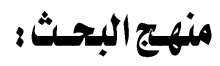

إستخدم الباحثان المنهج التجريبي باستخدام التصميم التجريبي لمجموعتين إحداهما

تجريبية والأخرى ضابطة باستذدام القياس البعدى للمجموعتين وذلك لملاءمته لطبيعة هذا البحث.

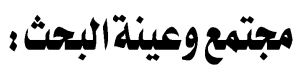
تم اختيار عينة البحث بالطريقة العمدية من تلميذات الصف الثانى بالمدرسة الإعدادية

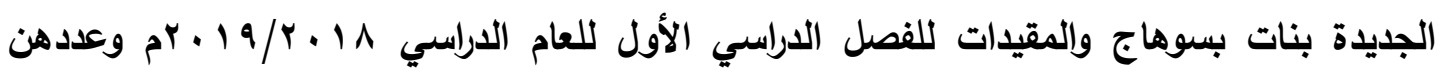
(V^)

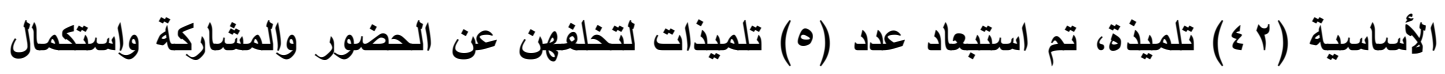

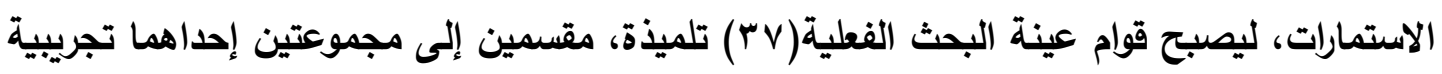

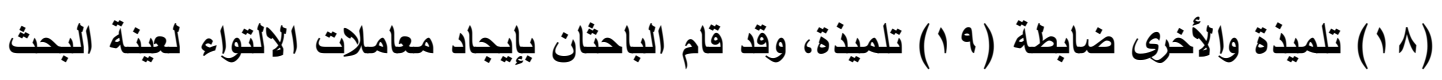

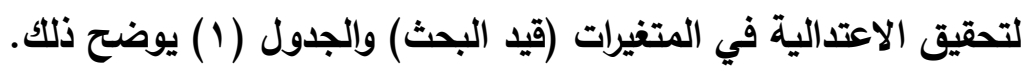

جدول (1)

التوصيف الإحصائي لمجتمع البحث في المتفيرات (قيد البحث)

$\vee \wedge=\dot{0}$

\begin{tabular}{|c|c|c|c|c|c|}
\hline الالتواء & الوسيط & الانحراف & المتوسط & المتغيرات & \\
\hline. $.7 \mathrm{~V}$ & $101 .$. & $7 . \leqslant \varepsilon$ & 10r. $\leqslant 0$ & الطول الكلى & \multirow{3}{*}{ متغيرات النمو } \\
\hline$\cdot .7 \leq-$ & $0 . .$. & $\vee \cdot \vee \wedge$ & $\varepsilon \Lambda . \varphi_{0}$ & وزن الجسم & \\
\hline $1 . \leqslant 0$ & $10 .$. & $\because v_{0}$ & 10.47 & العمر الزمنى & \\
\hline 1.11 & $11 r .0$. & $0 . r r$ & $110 . \leqslant V$ & مستوى الذكاء & 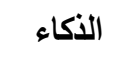 \\
\hline$\cdot r \varepsilon-$ & $17 .$. & -.99 & $10.9 r$ & الإرسال من أسفل أمامى مواجه & \multirow{3}{*}{ المهارية } \\
\hline $.09-$ & ч... & $1 . r \leqslant$ & $0 . V V$ & التمرير من أعلى وللأمام & \\
\hline $1 . . r$ & r... & $\cdot . \wedge \vee$ & $r . r$. & التمرير من أسفل & \\
\hline
\end{tabular}

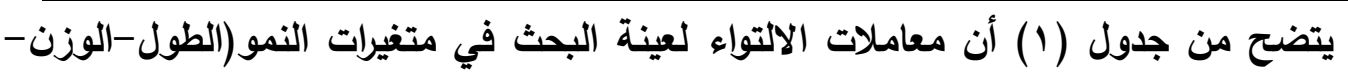

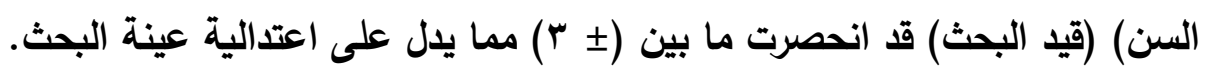


تأثير استخدام إستراتيجية الياءات الخمس (5E's)على عادات العقل وتعلم بعض المهارات الحركية في الكرة

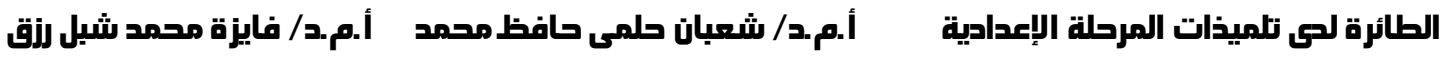

$$
\text { ورُوعَِ عند اختيار عينة البحث مايلى: }
$$

•أن يكون أفراد العينة من تلميذات الصف الثانى الإعدادي.

•المهارات التي تم استخدامها ضمن الخطة الأساسية من وزارة التربية والتعليم والمقررة

$$
\text { على تلاميذ الصف الثانى الإعدادي. }
$$

•سهولة الاتصال بعينة البحث وتواجدهن في ظروف دراسية واحدة.

•إمكانية توافر الأجهزة والأدوات داخل المدرسة والتي حددها الباحثان لتحقيق أهداف

$$
\text { البحث. }
$$

•موافقة إدارة المدرسة لتوفير كل التسهيلات، وتذليل العديد من العقبات، والتي قد يواجها الباحثان قبل وأثناء وبعد تطبيق البحث.

•سهولة الاتصال مع إدارة المدرسة وتوافر المساعدين من الزملاء داخل المدرسة لمساعدة الباحثان في القياسات المتعلقة بعينة البحث، وتفهمهم طبيعة إجراء

$$
\text { القياسات التي يتم استخدامها. }
$$

الأدواتوالأجهزة المستخدمة:

$$
\begin{aligned}
& \text { •جهاز الرستاميتر : لقياس الطول (لأقرب سم) والوزن (لأقرب كجم). } \\
& \text { • شريط قياس لقياس المسافات بالمتر . } \\
& \text { • ملعب كرة طائرة قانونى. } \\
& \text { • ساعة ايقاف: لقياس الزمن (ث). } \\
& \text { • كرات طائرة. } \\
& \text { • • كرات طبية }
\end{aligned}
$$

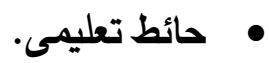

$$
\text { تكافؤمجموعتى البحث : تونتئ }
$$

تم تحقيق التكافؤ بين مجموعتى البحث التجريبية والضـابطة فى عادات العقل التى استهرفها

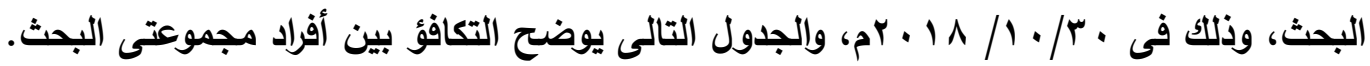




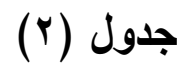

المتوسط الحسابى والانحراف المعيارى ودلالة الفروق بين القياسين القبليين للمجموعة

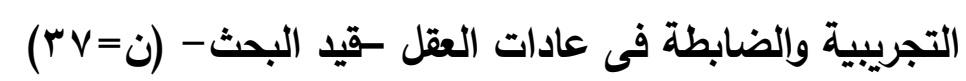

\begin{tabular}{|c|c|c|c|c|c|c|}
\hline \multirow{2}{*}{ قيمة } & \multicolumn{2}{|c|}{ المجموعة الضطة } & \multicolumn{2}{|c|}{ المجموعة التجيبة } & \multirow[t]{2}{*}{ عادات العقل } & \multirow[t]{2}{*}{ P } \\
\hline & $r \varepsilon \pm$ & $t^{p}$ & $1 \varepsilon \pm$ & p & & \\
\hline.$Y_{\Lambda}$ & $\bar{T}$ T.rY & $19 .$. & r.07 & $19.4 \pi$ & المثابرة & 1 \\
\hline$\because \vee \wedge$ & $1 . V r$ & $r . .01$ & $1 . \wedge \varepsilon$ & $r \cdot .11$ & التحكم بالاندفاع & $r$ \\
\hline$\because \varepsilon \varepsilon$ & r... & 10.4 & 1.90 & $1 \leq .99$ & التصور، الابداع والابتكار & $r$ \\
\hline .11 & r.or & r..1r & r.vA & r. ro & الاصغاء بفهم وتعاطف & $\varepsilon$ \\
\hline$\because \varepsilon \wedge$ & $r . r \varepsilon$ & $19.9 \mathrm{~V}$ & r.YT & $r \cdot r \varepsilon$ & التفكير فوق المعرفي & 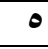 \\
\hline $.0 Y$ & r.OV & IV.r & $r . \varepsilon \varepsilon$ & IV.VA & تحري الدقة & 7 \\
\hline .17 & t.VT & $I V_{.}$. & 5.70 & 17.10 & التساؤل وحل المشكلات & 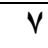 \\
\hline $.1 \mathrm{~V}$ & $r .79$ & $r \cdot .17$ & Y.VY & $r \cdot . \cdot$ & التفكير التبادلي أو الجماعي & $\Lambda$ \\
\hline$\cdot \sum r$ & r.Tร & $r \cdot . I^{\prime}$ & $r .07$ & $19.8 \mathrm{~V}$ & التفكير بمرونة & 9 \\
\hline .91 & $1.1 \varepsilon$ & IT.TE & 1.41 & IY.YA & تطبيق المعارف السابقة في مواقف جديدة & 1. \\
\hline$\because \leqslant 7$ & $1 . \leqslant 7$ & 17.41 & $1 . r \leq$ & 17.04 & التفكير والتو اصل بوضوح ودقة & 11 \\
\hline .10 & r.VT & $199 . \mathrm{YV}$ & r.AV & 199.11 & المقياس & مح \\
\hline
\end{tabular}

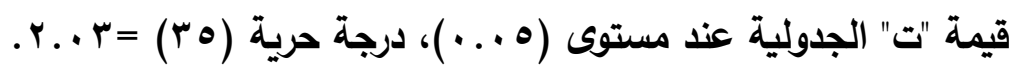

يتضح من الجدول السابق عدم وجود فروق دالة إحصائياً بين المجموعتين التجريبية والضابطة فى عادات العقل - قيد البحث-، مما يدل على تكافؤ المجموعتين. كما تم تحقيق التكافؤ بين مجموعتى البحث التجريبية والضابطة فى المهارات الحركية فى الكرة

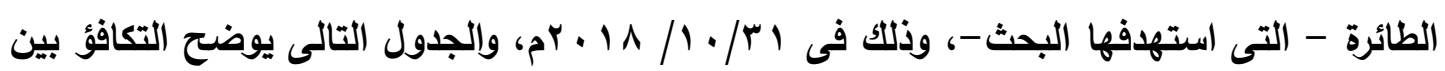

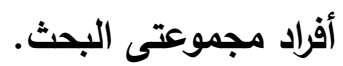

$$
\text { جدول (r) }
$$

المتوسط الحسابى والانحراف المعيارى ودلالة الفروق بين القياسين القبليين للمجموعتين

\begin{tabular}{|c|c|c|c|c|c|c|}
\hline \multirow{2}{*}{ قيمة (ت) } & \multicolumn{2}{|c|}{ المجموعة الضابطة } & \multicolumn{2}{|c|}{ المجموعة التجريبية } & \multirow{2}{*}{ المتغيرات } & \multirow[t]{2}{*}{ r } \\
\hline & $r \varepsilon \pm$ & م & $1 \varepsilon \pm$ & م & & \\
\hline 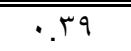 & 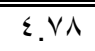 & 10Y.TV & $\varepsilon .07$ & 101.49 & الطول & 1 \\
\hline$\cdot . \leqslant V$ & V.rq & $0 . .1 \mathrm{~V}$ & $7 . Y_{1}$ & $\sum \Lambda . T V$ & وزن الجسم & r \\
\hline $.1 \cdot$ & $.0 \mathrm{Or}$ & 10.71 & $. r \leq$ & 10.11 & العمر الزمنى & $r$ \\
\hline 1.20 & $\cdot v \cdot$ & 10.94 & 1.4 & 10.10 & دقة الإرسال من أسفل لمراكز الملعب & $\varepsilon$ \\
\hline$\cdot . \leqslant \varepsilon$ & 1.14 & 7.91 & $1 . \leqslant \varepsilon$ & T.VY & دقة التمرير من أعلى على حائط & 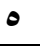 \\
\hline$\cdot .9 \pi$ & .01 & $r . \varepsilon 7$ & $\cdot . \wedge 7$ & r.Y & دقة التمرير من أسفل على حائط & 7 \\
\hline
\end{tabular}
التجريبية والضابطة فى متغيرات: الطول ووزن الجسم والعمر الزمنى والمهارات الحركية فى الكرة الطائرة -قيد البحث - (ن

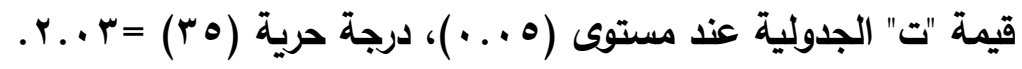


تأثير استخدام إستراتيجية الياءات الخمس (5E's)على عادات العقل وتعلم بعض المهارات الحركية في الكرة

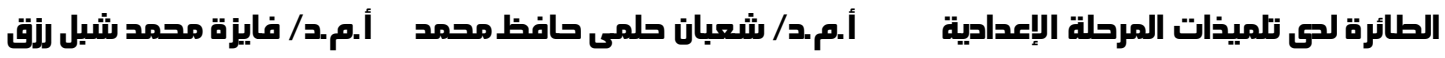

يتضـح مـن الجدول السـابق عدم وجـود فروق دالـة إحصـائياً بـين المجمـوعتين التجريبيـة

والضابطة فى الطول ووزن الجسم والعمر الزمنى والمهارات الحركية فى الكرة الطائرة -قيد البحث-،

مما يال على تكافؤ المجموعتين.

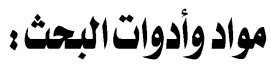

تتطلب طبيعة البحث استخدام مواد وأدوات متعددة يمكن تقسيمها كما يلي:

1 - وحدة الكرة الطائرة المقررة على تلميذات الصف الثانى الإعدادى بعد إعادة صياغتها وفقاً

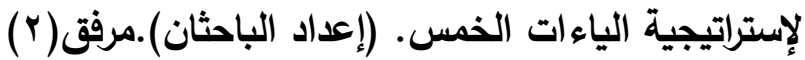

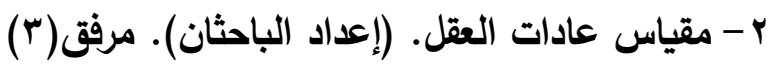

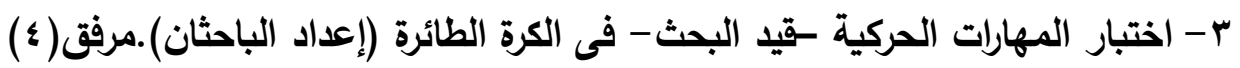

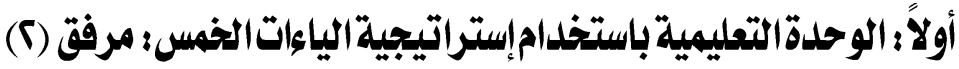

تم إعادة صياغة الوحدة التعليمية للكرة الطائرة المقررة على تلميذات الصف الثانى الإعدادى

وفقاً لاستراتيجية وخطوات الياءات الخمس..

وقد ورُوعِيَ عند إعادة صياغة هذه الوحدة ما يلى:

• أن يحقق المحتوى أهداف الوحدة التعليمية.

• مراعاة الفروق الفردية بين التلميذات.

• مشاركة جميع التلميذات في وقت واحد أثناء التريس.

• البساطة والتدرج والتنوع في محتوى الوحدة التعليمية.

• استثارة دافعية التلميذات نحو التعلم والمشاركة الإيجابية.

الإطار العام التففيذ محتوى دروس الوحدة دالتعليمية :

اسـغرق تـدريس الوحدة التعليميـة (؟ أسـابيع) بواقـع درس أسبوعيًا وبإجمـالي (؟ دروس)

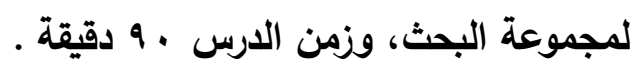

ثانياً: مقياس عاداتالعقل : (تصميم الباحثان)

قام الباحثان بتصميم مقياس عادات العقل في ضوء نموذج كوستا وكاليك Costa

K Kallick

ا

r. جمع البيانات باستخدام جميع الحواس. Gathering data through all sense

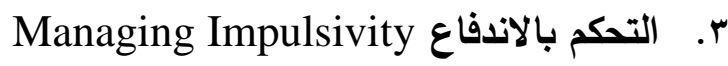

؛ Creating, imagining, innovating التصور، الابداع والابتكار

ه. الاصغاء بفهم وتعاطف Listening with understanding and empathy

7. 


\section{مجلــة سوهاج لعلوم وفنـون الترييـة البدنيـة والرياضـة - العـدد الثاني - يناير 19·مم}

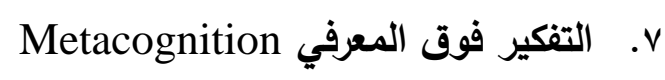

A. تحمل مسؤولية المخاطرة Taking Responsible Risks

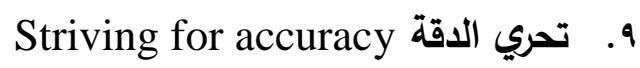

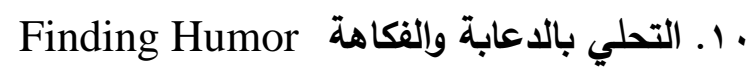

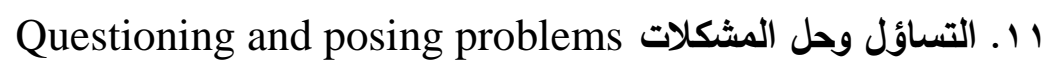

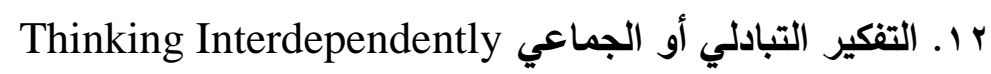

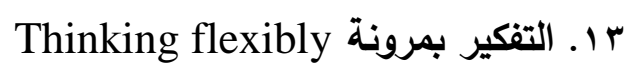

Applying past knowledge to new إ. تطبيق المعارف السابقة في مواقف جديدة situations

ما التفكير والتواصل بوضوح ودقة Thinking and Communicating with clarity and precision

17 Remaining open to continuous learning الاستعداد الائم للتعلم المستمر

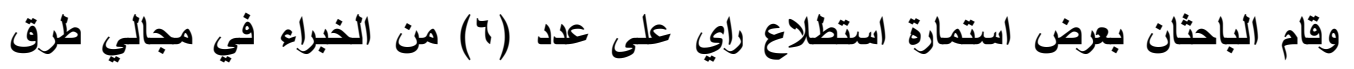

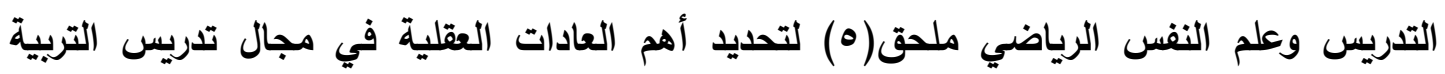

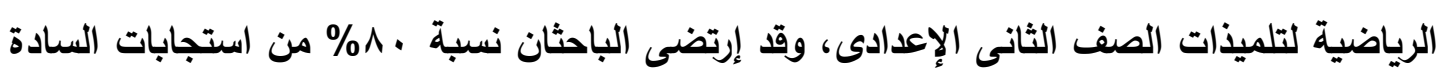

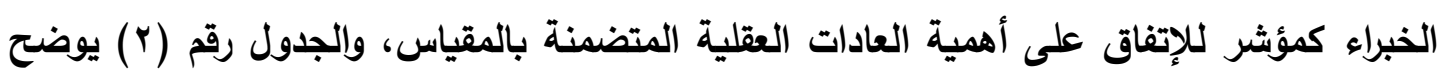
ذلك. 
تأثير استخدام إستراتيجية الياءات الخمس (5E's)على عادات العقل وتعلم بعض المهارات الحركية في الكرة

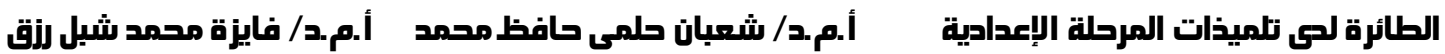

\section{جدول (\&)}

آراء الخبراء لأهم العادات العقلية المرتبطة بتدريس التربية الرياضية لتلميذات الصف الثانى الإعدادى

$1=\dot{0}$

\begin{tabular}{|c|c|c|c|}
\hline النسبة & الاستجابة & عادات العقل & م \\
\hline$\% 1 \ldots$ & 7 & 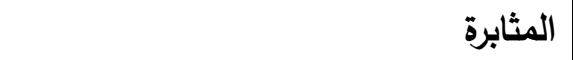 & 1 \\
\hline$\% 74.7 V$ & $\varepsilon$ & جمع البيانات باستخدام جميع الحواس & r \\
\hline$\% \wedge r . r r$ & $\bullet$ & التحكم بالاندفاع & r \\
\hline$\% 1 \ldots$ & 9 & التصور والابداع والابتكار & $\varepsilon$ \\
\hline$\% 1 \ldots$ & 9 & الاصغاء بفهم وتعاطف & $\bullet$ \\
\hline$\% \circ$. & $r$ & الاستجابة بـهشة وتساؤل & 7 \\
\hline$\% 1 \ldots$ & 7 & التفكير فوق المعرفي & $v$ \\
\hline$\% 74.7 V$ & $\varepsilon$ & تحمل مسؤولية المخاطرة & $\wedge$ \\
\hline$\% 1 \ldots$ & 7 & تحري الدقة & 9 \\
\hline$\% 74.7 V$ & $\varepsilon$ & التحلي بالد عابة والفكاهة & 1 . \\
\hline$\% 1 \ldots$ & 7 & التساؤل وحل المشكلات & 11 \\
\hline$\% \wedge r . r r$ & $\bullet$ & التفكير التبادلي أو الجماعي & ir \\
\hline$\% 1 \ldots$ & 7 & التفكير بمرونة & ir \\
\hline$\% 1 \ldots$ & 7 & تطبيق المعارف السابقة في مواقف جديدة & $1 \varepsilon$ \\
\hline$\% 1 \ldots$ & 7 & التفكير والتواصل بوضوح ودقة & 10 \\
\hline$\% 74.7 V$ & $\varepsilon$ & الاستعداد الدائم للتعلم المستمر & 17 \\
\hline
\end{tabular}

يتضح من الجدول رقم (؛) أن أهم عادات العقل في مجال تدريس التربية الرياضية لتلميذات الصف الثاني الإعدادي من وجهه نظر الخبراء (11) عادة عقلية بلغت نسبة إتفاق السادة الخبراء على أهميتها أكثر من ·^\% والتي ارتضاها الباحثان وهي عادات (المثابرة، التحمم بالاندفاع، التصور والإبداع والابتكار، الاصغاء بفهم وتعاطف، التفكير فوق المعرفي، تحري الاقة، التساؤل وحل المشكلات، التفكير التبادلي أو الجماعي، التفكير بمرونة، تطبيق المعارف السابقة في مواقف جديدة، التفكير والتواصل بوضوح ودقة). ثم قام الباحثان بوضع مجموعة من العبارات لتعبر عن كل عادة عقلية في ضوء المفهوم الخاص بكل عادة. وتم عرض العبارات مرة أخرى على نفس الخبراء لأخذ رأيهم في صياغة العبارة 
ومدي انتمائها للعادة العقلية. وبلغ اجمالي العبارات الخاصة بمقياس عادات العقل بعد التعديل ( V ) عبارة، موزعين كالتالي:

المثابرة (v عبارات)، التحكم بالاندفاع (v عبارات)، التصور والابداع والابتكار (ه عبارات)،

الاصغاء بفهم وتعاطف (V عبارات)، التفكير فوق المعرفي (V عبارات)، تحري الدقة (؟ عبارات)،

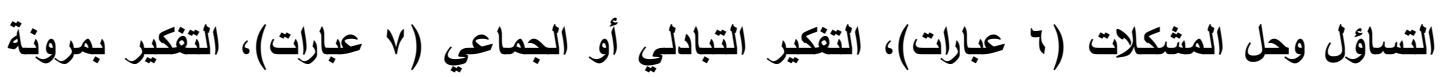
( V Vبارات)، تطبيق المعارف السابقة في مواقف جديدة (ه عبارات)، التفكير والتواصل بوضوح ودقة (ף عبارات). تقوم الطالبة بالإجابة على المقياس من خلال مقياس ليكرت الرباعي (يحدث دائما (ع درجات)، يحدث غالبا (ب درجات)، يحدث أحيانا (درجتان)، لا يحدث ابدا (درجة واحدة).

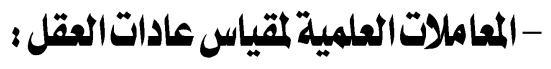
أ-صدق مقياس عاداتالعقل : صداق المحكمين.

قام الباحثان بحساب صدق مقياس عادات العقل عن طريق الصدق الظاهري وذلك بعرض

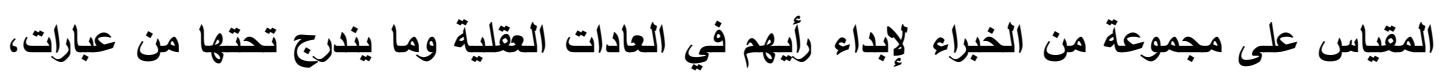
مما يجعل المقياس صادق من الناحية الظهرية وذلك بالإضافة إلى صدق الاتساق الداخلي.

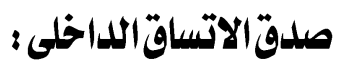

استخدم الباحثان صدق الاتساق الداخلي بالتطبيق على (؟ب\%) تلميذة من مجتمع البحث ومن خارج العينة الأساسية للبحث، وإيجاد معاملات الارتباط بين درجاتهن في كل عبارة مع مجموع درجة العادة العقلية الخاصة بها وفيما يلي الجدول الموضتح لهذه النتائج. 
تأثير استخدام إستراتيجية الياءات الخمس (5E's)على عادات العقل وتعلم بعض المهارات الحركية في الكرة

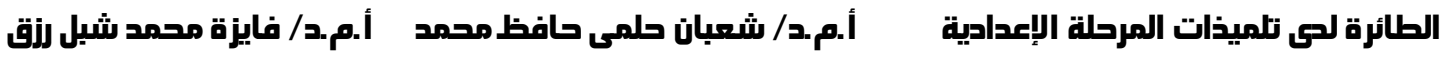

جدول (0)

معاملات الارتباط الداخلي بين درجات كل عادة عقلية والدرجة الكلية للمقياس $r q=\dot{0}$

\begin{tabular}{|c|c|c|c|}
\hline الارتباط معامل & عدد المفردات & الأبعاد الأساسية & b \\
\hline$* . . v 1 r$ & v & المثابرة & 1 \\
\hline$* . . \vee 70$ & v & التحكم بالاندفاع & $r$ \\
\hline$* . . \vee 91$ & 0 & التصور والابداع والابتكار & $r$ \\
\hline$\star . . V \cdot r$ & v & الاصغاء بفهم وتعاطف & $\varepsilon$ \\
\hline$\star^{\star} . \Delta \mathrm{Nu}_{\mathrm{T}}$ & $v$ & التفكير فوق المعرفي & $\bullet$ \\
\hline$\star . .9 \leq \leqslant$ & 7 & تحري الدقة & 9 \\
\hline$\star^{*} \cdot v \ldots$ & 7 & التساؤل وطرح المشكلات & $v$ \\
\hline$\star . . \vee 19$ & $\checkmark$ & التفكير التبادلي أو الجماعي & $\wedge$ \\
\hline${ }^{\star} . . T Y 1$ & $v$ & ا التفكير بمرونة & 9 \\
\hline$* . \vee \vee 79$ & 0 & تطبيق المعارف السابقة في مواقف جديدة & 1. \\
\hline$\star . . \vee T \leqslant$ & 7 & التفكير والتواصل بوضوح ودقة & 11 \\
\hline
\end{tabular}

يتضح من جدول (0) أن محددات الاختبار كانت ارتباطات درجاتها بالدرجة الكلية للاختبار

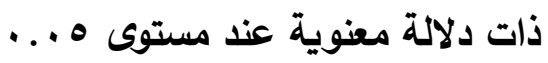


مجلـة سوهاج لعلوم وفنـونَ الترييـة اليدنيـة والرياضـة - العـد الثاني - يناير 19-مم

جدول (7)

معامل الارتباط بين درجة كل عبارة والعادة العقلية التى تنتمي اليها

ن

\begin{tabular}{|c|c|c|c|c|c|c|c|c|}
\hline \multicolumn{7}{|c|}{ ارقام العبارات } & \multirow{2}{*}{ الأبعاد الأسساسية } & \multirow[t]{2}{*}{ b } \\
\hline V & 9 & 0 & $\varepsilon$ & $r$ & $r$ & 1 & & \\
\hline$\star .79$. & $\star . . \wedge r \varepsilon$ & $\star$ *.VYO & $\star . .9 \cdot 1$ & ${ }^{\star} \cdot . \vee \vee \uparrow$ & $* . v \cdot r$ & $\star .711$ & | & 1 \\
\hline \multirow[t]{2}{*}{$\star \cdot \cdot V \cdot r$} & $\star . . \wedge \vee V$ & $\star$ *. V04 & $\star . .9 r \mu$ & $\star^{\star} \cdot v \cdots$ & $\star . .704$ & $\star . .791$ & | التحكم بالاندفاع & $r$ \\
\hline & & $*$. .AYr & $\star^{\star} . \vee \cdots$ & $\star . .794$ & $\star . V \cdot 7$ & $\star^{*} . V Y r$ & التصور ، الابداع والابتكار & $r$ \\
\hline$\star \cdot . \wedge \vee \wedge$ & $\star . . \vee 9 \wedge$ & $\star . .77 \varepsilon$ & $\star . . \vee 19$ & ${ }^{\star} \cdot . \vee \cdots$ & *... & $\star . \vee V Y V$ & |لاصغاء بفهم وتعاطف & $\varepsilon$ \\
\hline \multirow[t]{3}{*}{$\star \cdot . \wedge \cdot 1$} & $\star . . \wedge r 4$ & $\star . .719$ & $\star . . T Y 1$ & ${ }^{\star} \cdot .71 \leq$ & $\star .9 \leq \leq$ & $\star . . T 41$ & التفكير فوق المعرفي & $\bullet$ \\
\hline & $* \cdot . \wedge \wedge \vee$ & $\star . .179$ & $\star . . \vee \ldots$ & ${ }^{\star} . .794$ & $\star \cdot v \cdot 1$ & A.VKr & تحري الدقة & 7 \\
\hline & $\star . .711$ & $\star . .9 \leq \varepsilon$ & $\star . . \vee 19$ & $\star . \vee v$ & *..人r4 & $\star . . V V V$ & | التساؤل وحل المشكلات & v \\
\hline$\star \cdot \cdot v \cdot r$ & $* \cdot .9 \cdot r$ & $\star$ *.VYr & *..Tr1 & ${ }^{\star} . .71 \leq$ & $\star . .9 \leq \leq$ & $\star^{*} . .4 T 1$ & | التفكير التبادلي أو الجماعي & $\wedge$ \\
\hline \multirow[t]{3}{*}{$\star .9 \leq 1$} & $\star . \vee \cdots$ & $\star . \vee \vee 9 \wedge$ & ^. & ${ }^{\star} \cdot .179$ & $\star . \wedge \ldots$ & $\star .791$ & ا لتفكير بمرونة & 9 \\
\hline & & $* . . \vee 79$ & $\star . .70 r$ & ${ }^{\star} \cdot . \vee \vee \wedge$ & $\star . .179$ & A..v.r & تطبيق المعارف السابقة في مواقف جديدة & 1. \\
\hline & $* . \wedge 79$ & $\star . . \vee \neg \leq$ & $\star . . V Y 0$ & $\star . .79 V$ & $\star^{\star} \cdot . \vee V \varepsilon$ & $\star . . \vee 00$ & |التفكير والتواصل بوضوح ودقة & 11 \\
\hline
\end{tabular}

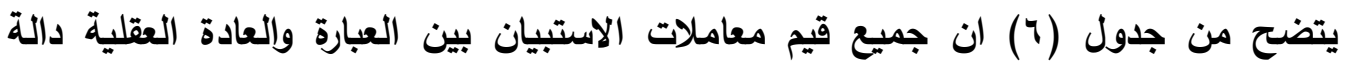

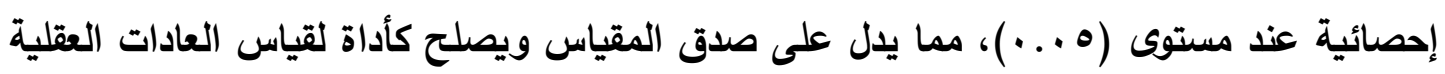
لاى التلميذات سمجموعة البحث-.

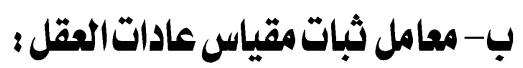
استخدم الباحثان طريقة التجزئة النصفية للتحقق من ثبات المقياس والجدول التالي يوضح ذلك. 
تأثير استخدام إستراتيجية الياءات الخمس (5E's)على عادات العقل وتعلم بعض المهارات الحركية في الكرة

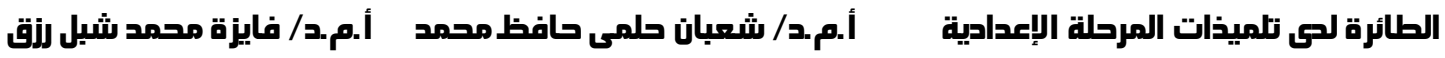

جدول (v)

الثبات بطريقة التجزئة النصفية لمقياس عادات العقل

rı $=\dot{ }$

\begin{tabular}{|c|c|c|c|c|c|c|}
\hline \multirow{2}{*}{$\begin{array}{l}\text { قيمة } \\
\text { (ر) }\end{array}$} & \multicolumn{2}{|c|}{ العبارات الزوجية } & \multicolumn{2}{|c|}{ العبارات الفردية } & \multirow{2}{*}{ عادات العقل } & \\
\hline & $r \varepsilon \pm$ & $r^{b}$ & $1 \varepsilon \pm$ & pa & & \\
\hline$\cdot .9 \leq 7$ & 1.11 & $9 . \leqslant \leqslant$ & 1.07 & $1 . .07$ & المثابرة & 1 \\
\hline $.9 \vee \leqslant$ & $1 . r V$ & $1 . . A r$ & $1 . \varepsilon \varepsilon$ & q.V V & التحكم بالاندفاع & r \\
\hline$\cdot . \wedge \vee 7$ & $1 . . r$ & 7.17 & 1.70 & 7.70 & التصور، الابداع والابتكار & $r$ \\
\hline. .949 & 1.11 & $9 . \leqslant Y$ & 1.20 & 9.91 & الاصفاء بفهم وتعاطف & $\varepsilon$ \\
\hline$\cdot .9 \leq 7$ & 1.11 & $\Lambda . \leqslant \varepsilon$ & 1.07 & 1.07 & التفكير فوق المعرفي & 0 \\
\hline$\cdot .9 \vee \leqslant$ & l. TV & A.AT & $1 . \varepsilon \varepsilon$ & 9.V V & تحري الدقة & 7 \\
\hline$\cdot . \wedge \vee \wedge$ & $1 . . r$ & 7.17 & 1.70 & $v .70$ & التساؤل وحل المشكلات & v \\
\hline $.90 \leqslant$ & 1.11 & $9.9 V$ & $1.1 r$ & $1 . . \wedge \mathrm{V}$ & التفكير التبادلي أو الجماعي & $\wedge$ \\
\hline$\cdot .9 \leq 7$ & 1.11 & $9 . \leqslant \varepsilon$ & 1.07 & 9.07 & التفكير بمرونة & 9 \\
\hline .977 & $1 . . r$ & $v_{.}$. & -.99 & T.r & تطبيـق المعـارف الســابقة في مواقـف & 1. \\
\hline$\cdot . \wedge \wedge \mathrm{r}$ & 1.14 & $\Lambda . Y \leq$ & 1.11 & $\Lambda . \leqslant V$ & التفكير والتواصل بوضوح ودقة & 11 \\
\hline. .949 & 1.20 & 94.91 & 1.71 & $91 . . \vee$ & مجموع المقياس & \\
\hline
\end{tabular}

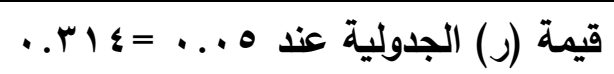

يتضح من الجدول (V) أن معاملات الثبات بطريقة التجزئة النصفية قد تراوحت بين

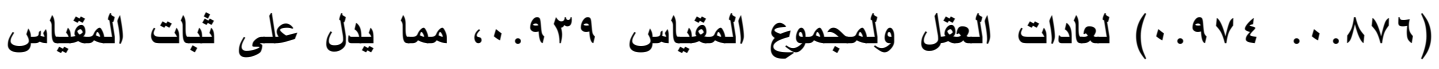
وصلاحيته كأداه تقيس عادات العقل لاى التلميذات - مجموعة البحث-.

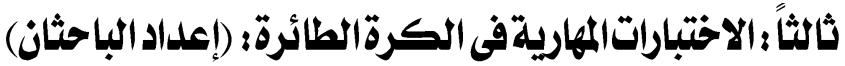
وذلك لقياس المهارات الحركية التالية:

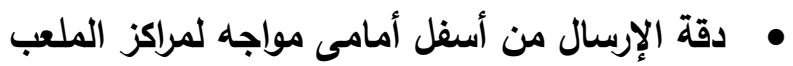

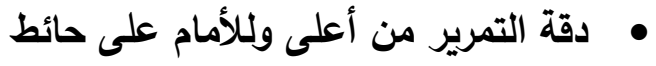

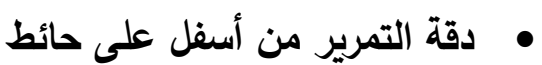


أ- معامل الصلدق للاختبارات المهاريةلفى الكرة الطائرة: صلدقالتمايزلاختبارات المهاريةفي الكرة الطائرة:

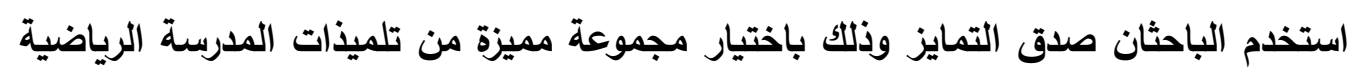

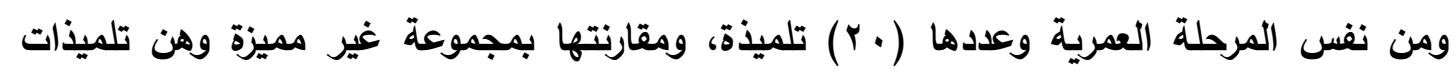

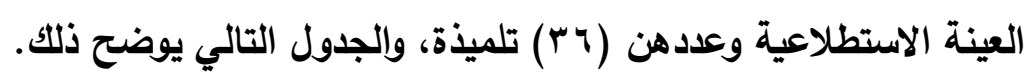

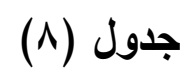

صدق الاختبارات المهارية فى الكرة الطائرة -قيد البحث-

$(r \cdot=r+r=10)$

\begin{tabular}{|c|c|c|c|c|c|}
\hline \multirow{2}{*}{ ق قيمة "ت" } & \multicolumn{2}{|c|}{ مجموعة مميزة } & \multicolumn{2}{|c|}{ مجموعة غير مميزة } & \multirow{2}{*}{ الاختبارات المهارية } \\
\hline & $r_{\varepsilon \pm}$ & $r^{r^{\prime}}$ & $1 \varepsilon \pm$ & مi & \\
\hline$* 1 \cdot, 1 \leqslant$ & $\cdot, 71$ & $r, \uparrow$. & $1, \cdot 1$ & $17, \ldots$ & دقة الإرسال لمراكز الملعب \\
\hline$* 11, V V$ & 1,01 & $1 r, 00$ & $1, r \mu$ & $\varepsilon, 90$ & دقة التمرير من أعلى على حائط \\
\hline$* 0,7$ & $1, Y 4$ & $1 \cdot, \wedge \wedge$ & $\cdot, 9 \mathrm{~V}$ & $r, \varepsilon$. & دقة التمرير من أسفل على حائط \\
\hline
\end{tabular}

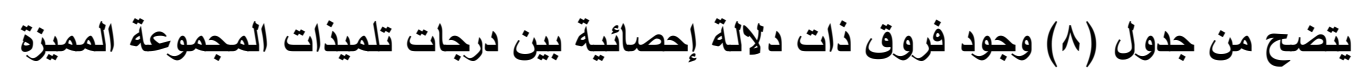

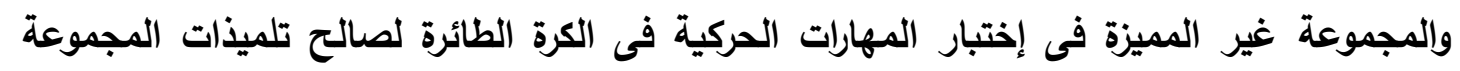

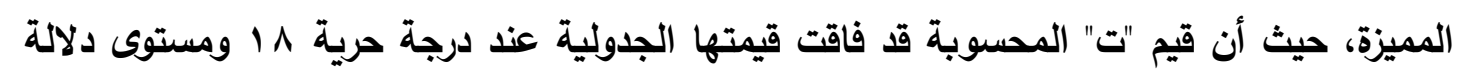

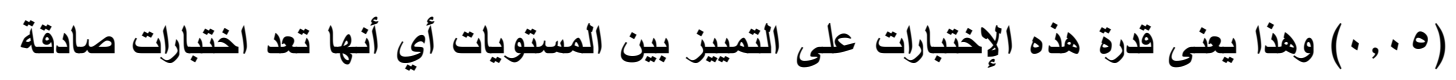
لقياس ما وضعت من أجلها. وهذا يدل على صدق الإختبارات المهارية ، وأنها تصلح كأداة لقياس المهارات الحركية-قيد

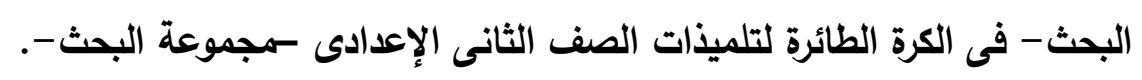

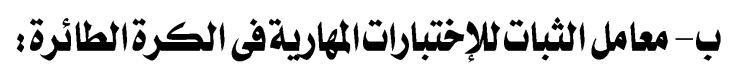

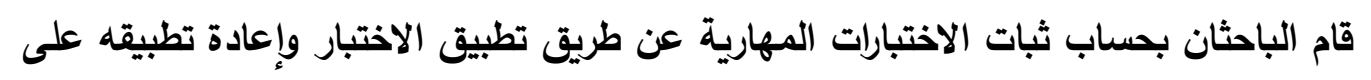

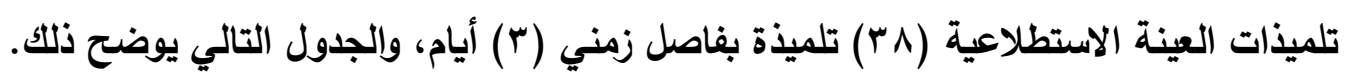


تأثير استخدام إستراتيجية الياءات الخمس (5E's)على عادات العقل وتعلم بعض المهارات الحركية في الكرة

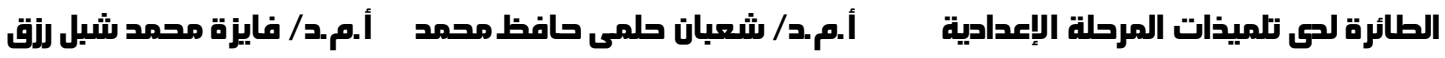

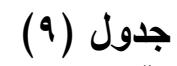

ثبات الإختبارات المهارية -قيد البحث- فى الكرة الطائرة

$r q=\dot{q}$

\begin{tabular}{|c|c|c|c|c|c|}
\hline \multirow{2}{*}{ 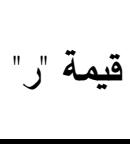 } & \multicolumn{2}{|c|}{ التطبيق الثاني } & \multicolumn{2}{|c|}{ التطبيق الأول } & \multirow{2}{*}{ الإختبارات المهارية } \\
\hline & $r \varepsilon \pm$ & $r_{p}$ & $1 \varepsilon \pm$ & p & \\
\hline$* \cdot 94$ & 1,11 & $17, r$. & $1, \cdot 1$ & $17, \cdots$ & دقة الإرسال من أسفل لمراكز الملعب \\
\hline$*$ & $1,0 Y$ & $\varepsilon, 9$. & I, & $\varepsilon, 90$ & دقة التمرير من أعلى على حائط \\
\hline$*, 9 \wedge$ & $\cdot, \leqslant 7$ & $r, 0$ & $\cdot, 9 \vee$ & $r, \varepsilon \cdot$ & دقة التمرير من أسفل على حائط \\
\hline
\end{tabular}

قيمة "ر" الجدولية عند مستوى معنوية ه ., . = ؛ ا آر, .

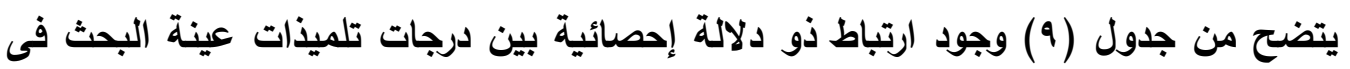

التطبيق الأول للاختبارات ودرجات التطبيق الثاني لنفس المجموعة الاستطلاعية بفاصل ثلاثة أيام ،

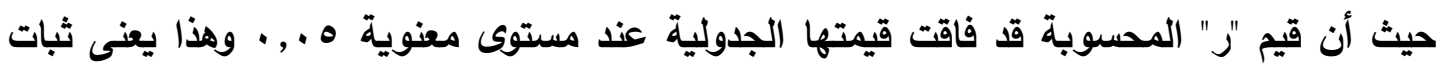

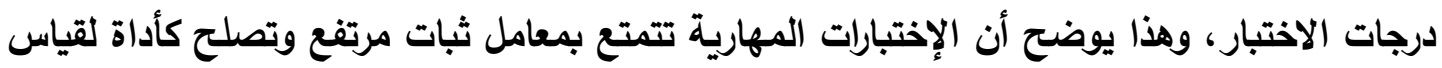
المهارات الحركية-قيد البحث- في الكرة الطائرة.

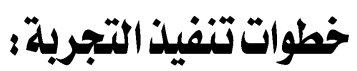

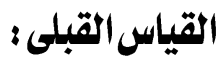

قام الباحثان بإجراء القياسات القبلية لمجموعتي البحث التجريبية والضابطة في المتفيرات

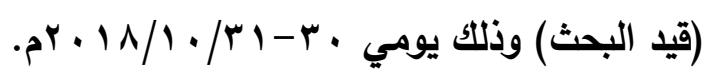

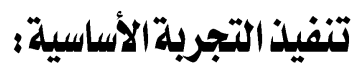

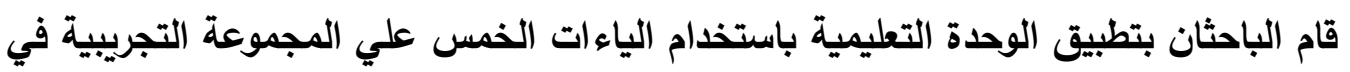

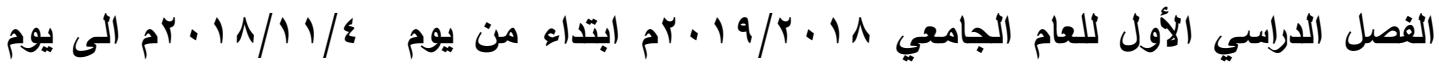

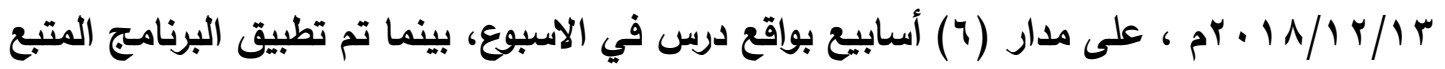

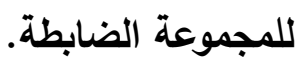

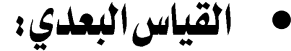

قام الباحثان بإجراء القياسات البعاية لمجموعتي البحث التجريبية والضابطة في المتغيرات

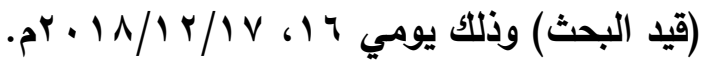

$$
\begin{aligned}
& \text { المعالجاتالإحصائية: }
\end{aligned}
$$

بناءً على أهداف البحث وفروضه تم تحديد الأسلوب الإحصائي المستخدم لتحليل البيانات

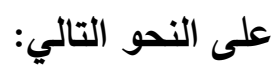

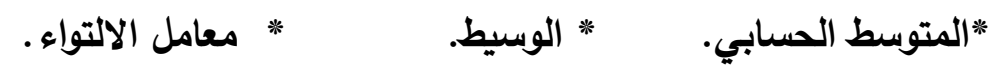




\section{مجلـة سوهاج لعلوم وفنـون الترييـة اليدنيـة والرياضـة - العـدد الثاني - يناير 19·م}

*الانحراف المعياري. اختبار "ت" للمجموعة الواحدة والمجموعتين

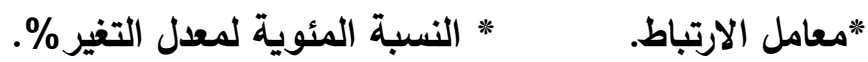

عرض النتائج ومناقشتهاوتفسيرهاء

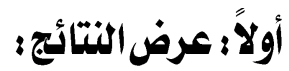

- عرض النتائج المتعلقة بالفرضين الأول والثانى من فروض البحث والذان ينصان على :

"يوجد فرق دال إحصائياً عند مستوى (ه...) بين متوسطى القياسين القبلي والبعدي

للمجموعة التجريبية في عادات العقل لصالح القياس البعدي.

"يوجد فرق دال إحصائياً عند مستوى (ه... • بين متوسطى القياسين القبلي والبعدي

للمجموعة الضابطة في عادات العقل لصالح القياس البعدي".

جدول (1.)

دلالة الفروق بين متوسطات القياسين القبلي والبعدي في عادات العقل

(قيد البحث) لمجموعة البحث التجريبية

\begin{tabular}{|c|c|c|c|c|c|c|c|}
\hline \multirow{2}{*}{ قيمة } & \multirow{2}{*}{ التحسنة \% } & \multicolumn{2}{|c|}{ القياس البعدي } & \multicolumn{2}{|c|}{ القياس القبلي } & \multirow{2}{*}{ عادات العقل } & \multirow[t]{2}{*}{ b } \\
\hline & & 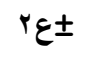 & th & 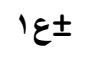 & p & & \\
\hline$* 0.00$ & r...q & r.VA & ro.s. & r.0T & 19.rT & المثابرة & 1 \\
\hline$* 4 .$. & $r \varepsilon . \varepsilon V$ & $1.9 V$ & ro..r & $1 . \wedge \varepsilon$ & $r \cdot .11$ & التحكم بالاندفاع & r \\
\hline *V.Y & Yl.Vo & r..r & 11..Yo & 1.90 & $1 \leq .99$ & التصور، الابداع والابتكار & $r$ \\
\hline$* \varepsilon .91$ & r). & r.A9 & ro.V $\varepsilon$ & r.V^ & ri.ro & الاصغاء بفهم وتعاطف & $\varepsilon$ \\
\hline *N. To & $r \cdot . \leqslant 0$ & r.ro & $r \leq .0$. & r.ru & $r \cdot . r \varepsilon$ & التفكير فوق المعرفي & 0 \\
\hline$* V . r \leq$ & 11.9 & T.TV & YI.Is & r. $\varepsilon \varepsilon$ & IV.VA & تحري الدقة & 7 \\
\hline$* 0 . \leqslant \varepsilon$ & $r \cdot . \wedge \leq$ & r.VT & r. T & r.70 & 17.10 & التساؤل وحل المشكلات & V \\
\hline *N. M & $r \cdot . \wedge 0$ & r.91 & $r \leq .1 V$ & r.VT & $r \ldots$ & التفكير التبادلي أو الجماعي & $\wedge$ \\
\hline$* q . . r$ & r.. rq & r.74 & rr.qA & r.07 & $19.8 \mathrm{~V}$ & التفكير بمرونة & 9 \\
\hline$* 11 . \leqslant V$ & rᄉ.Ar & 1.49 & IV.IV & $1 . Y_{1}$ & IT.TA & جبيدة المعارف السابقة في مواقف & 1. \\
\hline$* 1 \cdot 1$ & 5.17 & $1.0 r$ & r).71 & $1 . r \varepsilon$ & 17.04 & التفكير والتواصل بوضوح ودقة & 11 \\
\hline$* \vee . \neg \wedge$ & Y纟.YT & r.97 & $r \leqslant V . \leqslant r$ & Y.AV & $\begin{array}{c}199.1 \\
r\end{array}$ & & \\
\hline
\end{tabular}

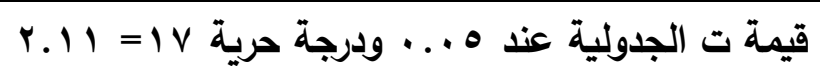


تأثير استخدام إستراتيجية الياءات الخمس (5E's)على عادات العقل وتعلم بعض المهارات الحركية في الكرة

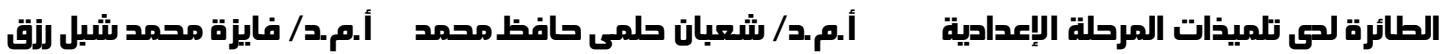

يتضح من جدول (· (1) وجود فروق ذات دلالة إحصائية بين القياسين القبلي والبعدي للمجموعة التجريبية في جميع عادات العقل (المثابرة، التحكم بالاندفاع، التصور والابداع والابتكار، الاصفاء بفهم وتعاطف، التفكير فوق المعرفي، تحري الدقة، التساؤل وحل المشكلات، التفكير التبادلي أو الجماعي، التفكير بمرونة، تطبيق المعارف السابقة في مواقف جديدة، التفكير والتواصل

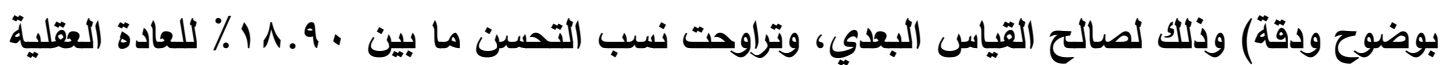

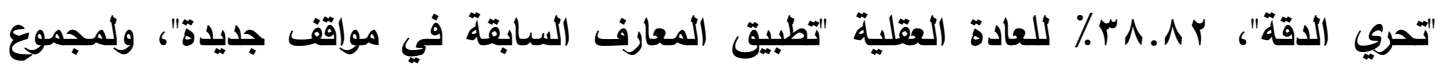

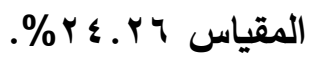

جدول (11)

دلالة الفروق بين متوسطات القياسين القبلي والبعدي في عادات العقل

(قيد البحث) لمجموعة البحث الضابطة

\begin{tabular}{|c|c|c|c|c|c|c|c|}
\hline \multirow{2}{*}{ قيمة } & \multirow{2}{*}{ التحسنة } & \multicolumn{2}{|c|}{ القياس البعدي } & \multicolumn{2}{|c|}{ القياس القبلي } & \multirow{2}{*}{ عادات العقل } & \multirow[t]{2}{*}{ p } \\
\hline & & $r \varepsilon \pm$ & ק & l $\varepsilon \pm$ & ما & & \\
\hline. To & $r .01$ & r.A. & 19.71 & T.YT & $19 .$. & المثابرة & 1 \\
\hline.$\wedge \wedge$ & Y... & r... & r... & $1 . V r$ & $r . .01$ & التحكم بالاندفاع & $r$ \\
\hline $1 . \cdot 1$ & $1 . \leqslant 7$ & t. t & $10 . r \leq$ & r... & $10 .+r$ & التصور والابداع والابتكار & $\mu$ \\
\hline 1.11 & $\varepsilon . \cdot r$ & $r .91$ & Y).91 & r.or & r... & الاصغاء بفهم وتعاطف & $\varepsilon$ \\
\hline..$Y_{1}$ & $\because v$ & $r . r \leq$ & $r . .11$ & r.rs & $19.9 V$ & التفكير فوق المعرفي & ○ \\
\hline I.r & $r .+r$ & $r . \varepsilon r$ & 18.79 & r.OV & IV.TE & ت تحري الدقة & 7 \\
\hline$. .7 \leq$ & r... & r.AV & IV.r & r.vr & $1 v \ldots$ & التساؤل وحل المشكلات & V \\
\hline.$\wedge \varepsilon$ & S.T & T.tro & $r 1 . . r$ & r.79 & $r \cdot .17$ & التفكير التبادلي أو الجماعي & $\Lambda$ \\
\hline$\because V V$ & $r .1 \varepsilon$ & $r . v i$ & $r \cdot .00$ & r.rs & $r \cdot .1 r$ & التفكير بمرونة & 9 \\
\hline. .79 & 1.11 & 1.79 & IT.VA & $1.1 \leq$ & IT.TE & جطبيق المعارف السابقة في مواقف & 1. \\
\hline..$\leqslant V$ & $1 . V T$ & 1.71 & 17.09 & $1 . \leqslant 7$ & $\mid 7 . M$ & التفكير والتواصل بوضوح ودقة & 11 \\
\hline .99 & T.TV & r.01 & $\begin{array}{c}r \cdot r \cdot q \\
q\end{array}$ & r.VT & $\begin{array}{c}199 . r \\
V\end{array}$ & ع المقياس & \\
\hline
\end{tabular}

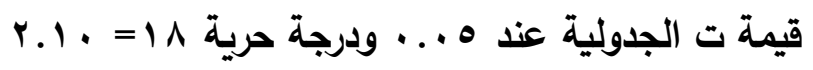

يتضح من الجدول (1 1) عدم وجود فروق ذات دلالة إحصائية بين القياسين القبلي والبعدي للمجموعة الضابطة في جميع عادات العقل (المثابرة، التحكم بالاندفاع، التصور والابداع والابتكار، 
الاصفاء بفهم وتعاطف، التفكير فوق المعرفي، تحري الاقة، التساؤل وحل المشكلات، التفكير

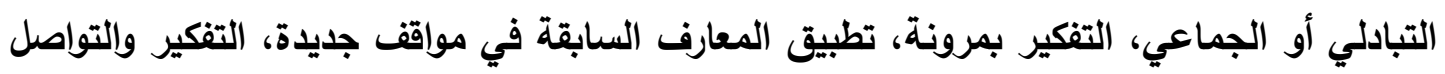

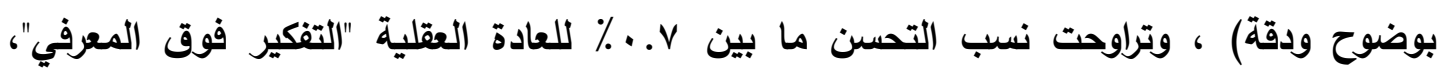

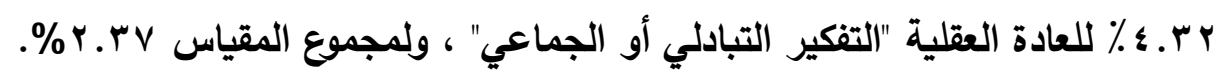

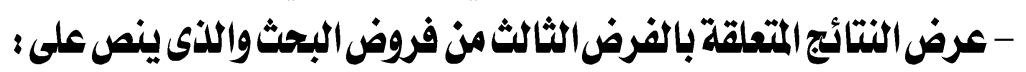

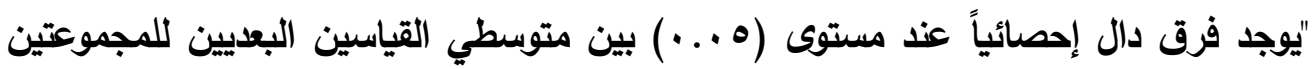

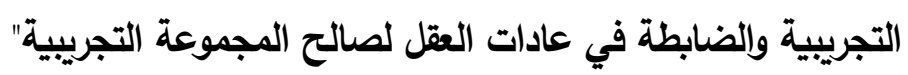

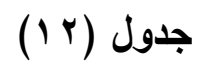

دلالة الفروق بين متوسطات القياسين البعديين في عادات العقل

(قيد البحث) لمجموعتى البحث التجريبية والضابطة

\begin{tabular}{|c|c|c|c|c|c|c|}
\hline \multirow{2}{*}{$\begin{array}{l}\text { قيمة } \\
\text { (ت) }\end{array}$} & \multicolumn{2}{|c|}{ المجموعة الضابطة } & \multicolumn{2}{|c|}{ المجموعة التجريبية } & \multirow{2}{*}{ عادات العقل } & \multirow{2}{*}{$\hat{r}$} \\
\hline & $r \varepsilon \pm$ & p & 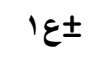 & ما & & \\
\hline$* \Upsilon . .1$ & r.A. & 19.71 & r.VA & ro.s. & المثابرة & 1 \\
\hline$*\rceil .$. & r... & $r \ldots$ & $1.9 \mathrm{~V}$ & ro..r & التحكم بالاندفاع & r \\
\hline$* \varepsilon .19$ & $r . r \leq$ & $10 . r \leq$ & $r . . r$ & 1N.ro & التصور والابداع والابتكار & $r$ \\
\hline * & $r .91$ & $r 1.91$ & r.^9 & ro.V $\varepsilon$ & الاصغاء بغهم وتعاطف & $\varepsilon$ \\
\hline$* 0.74$ & Y. Y $\leq$ & $r \cdot .11$ & 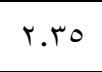 & $r \leq .0$. & التفكير فوق المعرفي & 0 \\
\hline$* \varepsilon \ldots$ & $r . \varepsilon r$ & 18.79 & r.TV & Y). $1 \leq$ & تحري الدقة & 7 \\
\hline$* r .19$ & r.AV & IV.ts & t.VT & $r \cdot . r t$ & التساؤل وحل المشكلات & V \\
\hline$* r .0 r$ & סקוr & $r . . r$ & r.91 & $r \leq .1 V$ & التفكير التبادلي أو الجماعي & $\Lambda$ \\
\hline$*$ *V^ & Y.VI & $r . .00$ & r.7T & $r+9 \Lambda$ & التفكير بمرونة & 9 \\
\hline *N.rV & 1.79 & Ir.VA & $1 . r 9$ & IV.IV & جطيق المعارف السابقة في مواقف & 1. \\
\hline$* q . r \wedge$ & 1.71 & 17.09 & $1.0 r$ & Y..TA & التفكير والتواصل بوضوح ودقة & 11 \\
\hline $\begin{array}{c}\leq 7.9 . \\
*\end{array}$ & r.01 & $\begin{array}{c}r \cdot r . q \\
q\end{array}$ & Y.97 & $\begin{array}{c}r \leq V . \varepsilon \\
r\end{array}$ & ع المقياس & 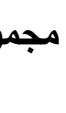 \\
\hline
\end{tabular}

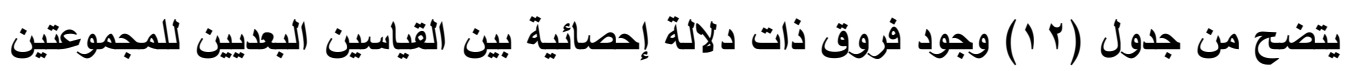

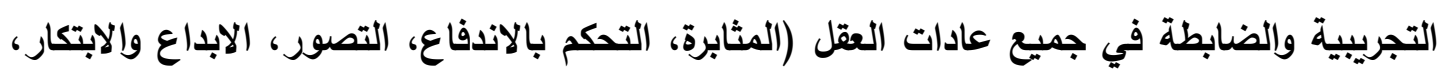


تأثير استخدام إستراتيجية الياءات الخمس (5E's)على عادات العقل وتعلم بعض المهارات الحركية في الكرة

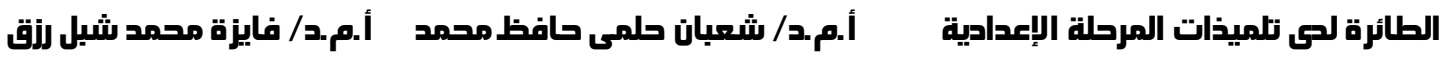

الاصغاء بفهم وتعاطف، التفكير فوق المعرفي، تحري الاقة، التساؤل وحل المشكلات، التفكير التبادلي أو الجماعي، التفكير بمرونة، تطبيق المعارف السابقة في مواقف جديدة، التفكير والتواصل بوضوح ودقة) لصالح القياس البعدي للمجموعة التجريبية.

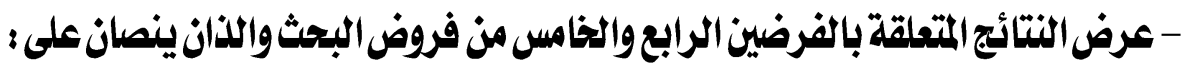

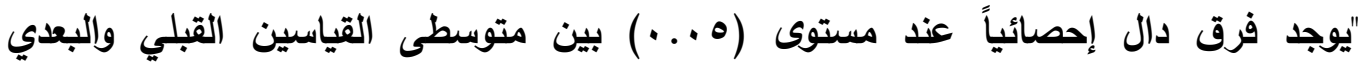
للمجموعة التجريبية في تعلم بعض المهارات الحركية في الكرة الطائرة لصالح القياس البعدي". و"يوجد فرق دال إحصائياً عند مستوى (ه ...) بين متوسطى القياسين القبلي والبعدي للمجموعة الضابطة في تعلم بعض المهارات الحركية في الكرة الطائرة لصالح القياس البعدي.

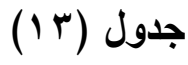

دلالة الفروق بين متوسطات القياسين القبلي والبعدي في الاختبارات المهارية في الكرة الطائرة (قيد البحث) لمجموعة البحث التجريبية

$1 \Lambda=\dot{0}$

\begin{tabular}{|c|c|c|c|c|c|c|c|}
\hline \multirow{2}{*}{ قيمة } & \multirow{2}{*}{ التحسنة } & \multicolumn{2}{|c|}{ القياس البعدي } & \multicolumn{2}{|c|}{ القياس القبلي } & \multirow{2}{*}{ الاختبارات المهاريـة } & \multirow[t]{2}{*}{ b } \\
\hline & & 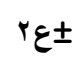 & ما & $1 \varepsilon \pm$ & ما & & \\
\hline r, & Yq.r人 & 1.91 & 19.17 & 1.51 & 10.10 & الملعب الإرسال من أسفل لمراكز & 1 \\
\hline$* 7.01$ & VT.IV & 1.174 & $11.0 \mathrm{~V}$ & $1 . \varepsilon \varepsilon$ & T.VY & دقة التمرير من أعلى على حائط & $r$ \\
\hline$* \varepsilon, \varepsilon \vee$ & MT.YE & $\because .9 \leq$ & R.ru &.$\wedge 1$ & $r . r \leq$ & دقة التمرير من أسفل على حائط & $r$ \\
\hline
\end{tabular}

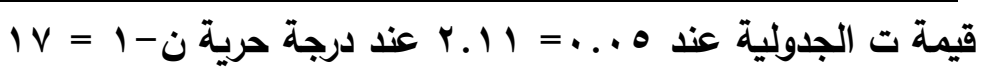

يتضح من جدول (r) وجود فروق ذات دلالة إحصائية بين القياسين القبلي والبعدي للمجموعة التجريبية في جميع الاختبارات المهارية في الكرة الطائرة (دقة الإرسال من أسفل لمراكز الملعب، دقة التمرير من أعلى على حائط، دقة التمرير من أسفل على حائط) وذلك لصالح القياس

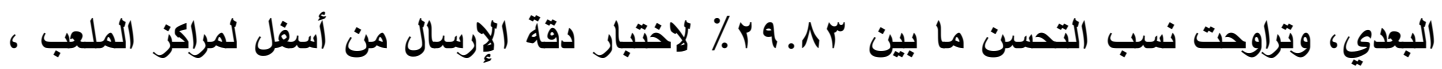

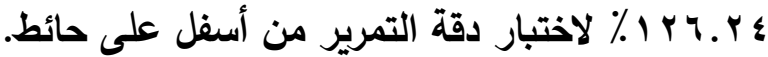




\section{جدول (؛ 1)}

دلالة الفروق بين متوسطات القياسين القبلي والبعدي في الاختبارات المهارية

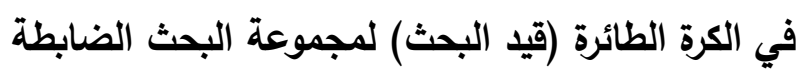

$19=\dot{0}$

\begin{tabular}{|c|c|c|c|c|c|c|c|}
\hline \multirow{2}{*}{ قيمة } & \multirow{2}{*}{ التحسن \% } & \multicolumn{2}{|c|}{ القياس البعدي } & \multicolumn{2}{|c|}{ القياس القبلي } & \multirow{2}{*}{ الاختبارات المهارية } & \multirow[t]{2}{*}{ p } \\
\hline & & $r \varepsilon \pm$ & p & $1 \varepsilon \pm$ & ما & & \\
\hline *r.OV & $1 \cdot . r r$ & $1 . \wedge$. & $1 V .07$ & $\therefore \vee$ & 10.94 & دقة الإرسال من أسفل لمراكز الملعب & 1 \\
\hline$* \gamma . \leqslant 0$ & rv..o & 1.10 & १.६จ & 1.14 & 7.91 & دقة التمرير من أعلى على حائط & r \\
\hline$* 9.91$ & $01 . \leqslant 0$ & $\because V V$ & $0 . r \leq$ &. .01 & r.\&T & دقة التمرير من أسفل على حائط & $r$ \\
\hline
\end{tabular}

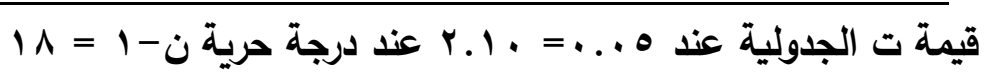

يتضح من الجدول (\& 1) وجود فروق ذات دلالة إحصائية بين القياسين القبلي والبعدي

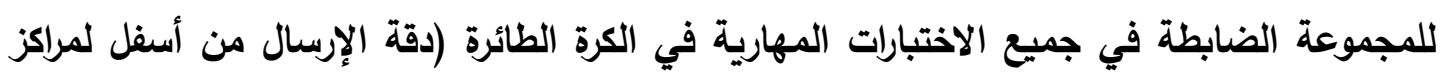

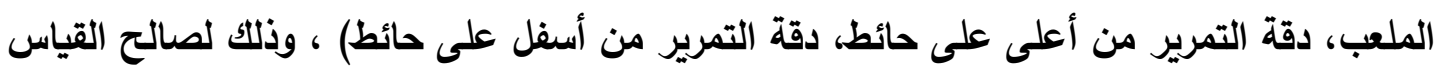

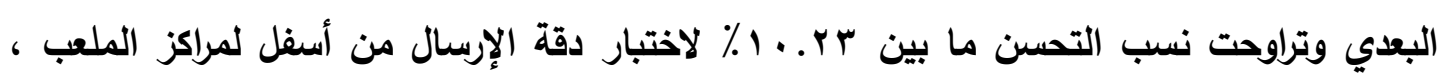
0 ـ ـ 1 \% لاختبار دقة التمرير من أسفل على حائط.

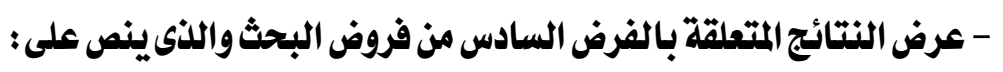

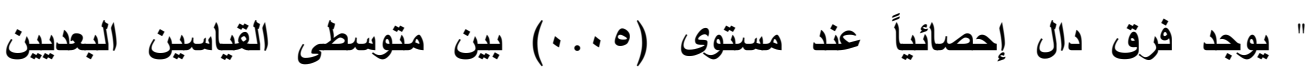
للمجموعتين التجريبية والضابطة في تعلم بعض المهارات الحركية في الكرة الطائرة لصالح المجموعة لـونئ التجريبية " المجوعين

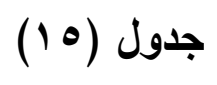

دلالة الفروق بين متوسطات القياسين البعايين في الاختبارات المهارية

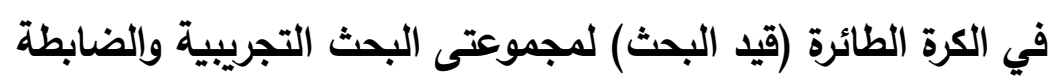
$19=r \dot{ن} 1 \Lambda=10$

\begin{tabular}{|c|c|c|c|c|c|c|}
\hline \multirow{2}{*}{ قيمة } & \multicolumn{2}{|c|}{ المجموعة الضابطة } & \multicolumn{2}{|c|}{ المجموعة التجريبية } & \multirow{2}{*}{ الاختبارات المهارية } & \multirow{2}{*}{ ? } \\
\hline & $r^{\prime} \varepsilon^{ \pm}$ & ip & $\varepsilon^{ \pm}$ & pe & & \\
\hline *T.TY & $1 . \wedge$. & 17.04 & 1.91 & $19 . \wedge 7$ & دقة الإرسال من أسفل لمراكز الملعب & 1 \\
\hline *E.T. & 1.10 & q.६V & $1 . v 4$ & $11.0 \mathrm{~V}$ & دقة التمرير من أعلى على حائط & r \\
\hline$* Y \cdot r)$ &.. $\mathrm{VV}$ & $0 . r \leq$ & $.9 \varepsilon$ & V.rr & دقة التمرير من أسفل على حائط & $r$ \\
\hline
\end{tabular}

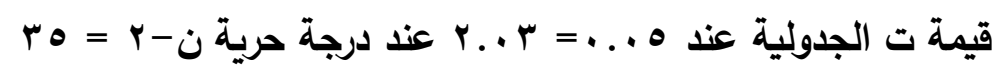


تأثير استخدام إستراتيجية الياءات الخمس (5E's)على عادات العقل وتعلم بعض المهارات الحركية في الكرة

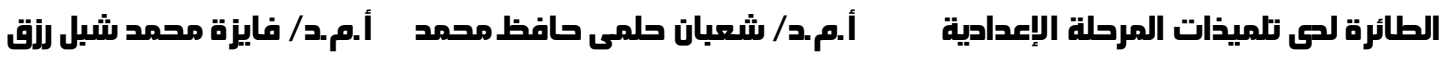

يتضح من الجدول (10) وجود فروق ذات دلالة إحصائية بين القياسين البعديين للمجموعتين التجريبية والضابطة في جميع الاختبارات المهارية في الكرة الطائرة (دقة الإرسال من أسفل لمراكز الملعب، دقة التمرير من أعلى على حائط، دقة التمرير من أسفل على حائط) لصالح

القياس البعدي للمجموعة التجريبية.

ثانياً: مناقشة النتائججوتفسيرها :

- مناقشة الفروض الأول والثاني والثالث من فروض البحث وتفسيرهم والذين ينصوا على : 1 - يوجد فرق دال إحصائياً عند مستوى (0 . . ·) بين متوسطى القياسين القبلي والبعدي للمجموعة التجريبية في عادات العقل لصالح القياس البعدي. ץ - يوجد فرق دال إحصائياً عند مستوى (0 . . •) بين متوسطى القياسين القبلي والبعدي للمجموعة الضابطة في عادات العقل لصالح القياس البعدي. ب- يوجد فرق دال إحصائياً عند مستوى (ه ...) بين متوسطى القياسين البعديين للمجموعتين التجريبية والضابطة في عادات العقل لصالح المجموعة التجريبية. يتضح من الجدول (• (1) وجود فروق ذات دلالة إحصائية بين القياسين القبلي والبعدي للمجموعة التجريبية في جميع عادات العقل (المثابرة، التحكم بالاندفاع، التصور، الابداع والابتكار، الاصفاء بفهر

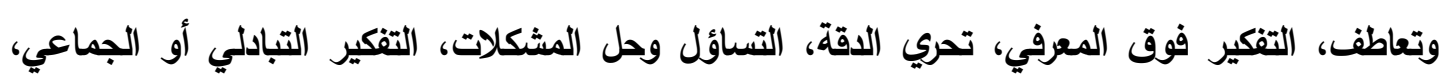
التفكير بمرونة، تطبيق المعارف السابقة في مواقف جليدة، التفكير والتواصل بوضوح ودقة) وذلك لصالح

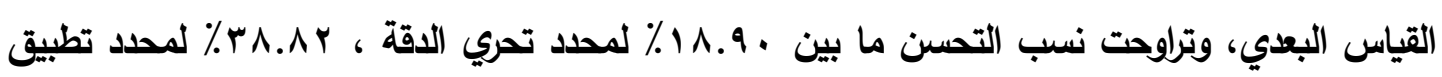

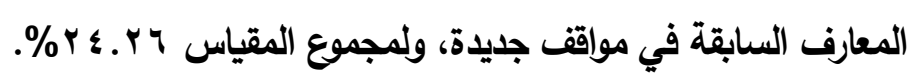
ويتضح من الجدول (11) علم وجود فروق ذات دلالة إحصائية بين القياسين القبلي والبعدي للمجموعة الضابطة في جميع عادات العقل (المثابرة، التحكم بالاندفاع، التصور والابداع والابتكار، الاصغاء بفهم وتعاطف، التفكير فوق المعرفي، تحري الدقة، التساؤل وحل المشكلات، التفكير التبادلي أو الجماعي، التفكير بمرونة، تطبيق المعارف السابقة في مواقف جديدة، التفكير والتواصل بوضوح ودقة) ، وتراوحت

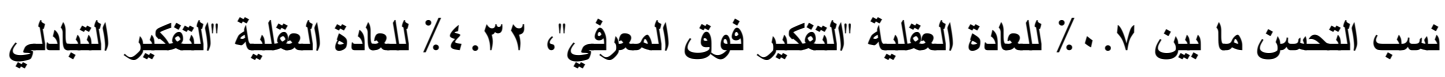

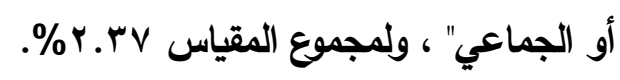

ويتضح من الجدول (Y I) وجود فروق ذات دلالة إحصائية بين القياسين البعديين للمجموعتين التجريبية والضابطة في جميع عادات العقل (المثابرة، التحكم بالاندفاع، التصور، الابداع والابتكار، الاصغاء بفهم وتعاطف، التفكير فوق المعرفي، تحري الدقة، التساؤل وحل المشكلات، التفكير التبادلي أو الجماعي، التفكير بمرونة، تطبيق المعارف السابقة في مواقف الإنفاء جديدة، التفكير والتواصل بوضوح ودقة) لصالح القياس البعدي للمجموعة التجريبية. 
ويُعزى الباحثان ذلك إلى تأثير استخدام إستراتيجية الياءات الخمس في تحسين عادات العقل

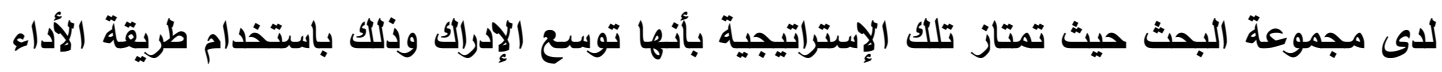

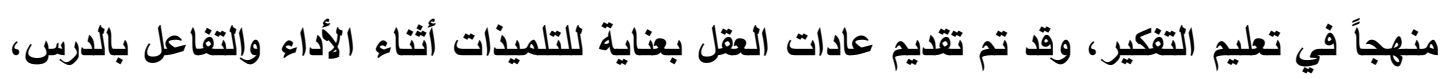

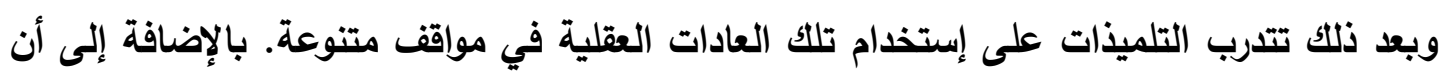

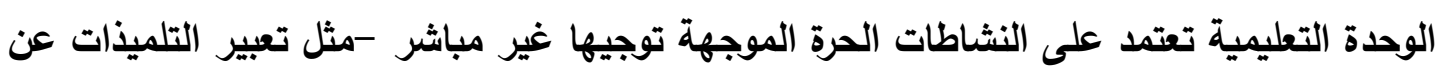

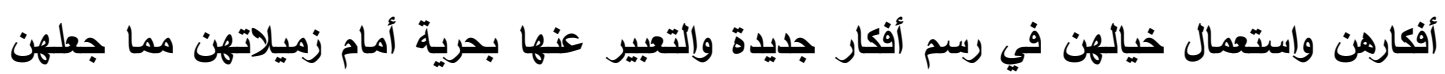

$$
\text { قادرات على الابداع. }
$$

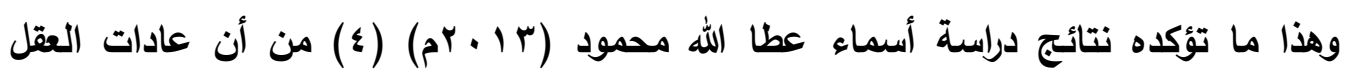

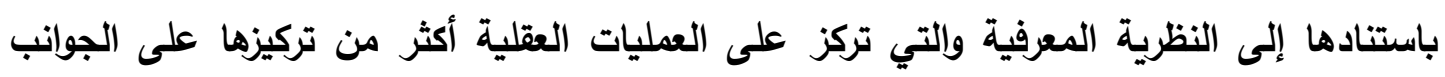

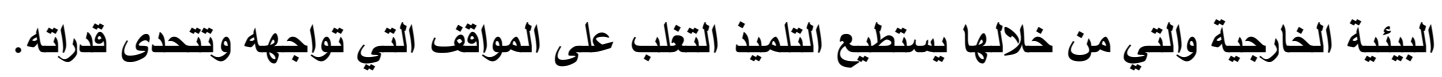

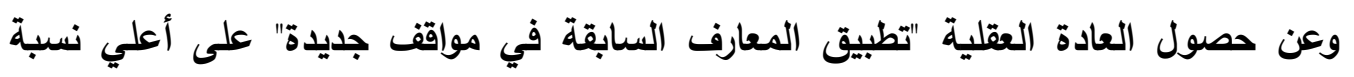

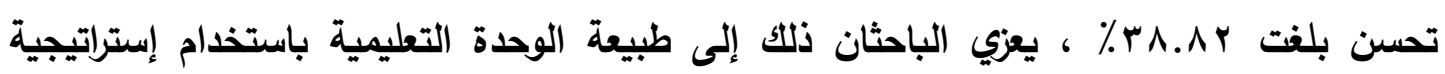

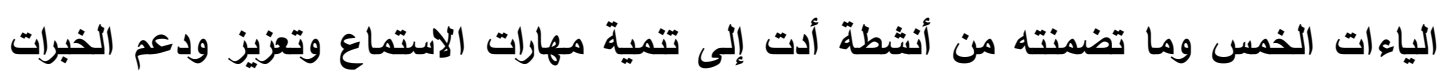
السابقة والتعلم من خبرات الفشل والنجاح.

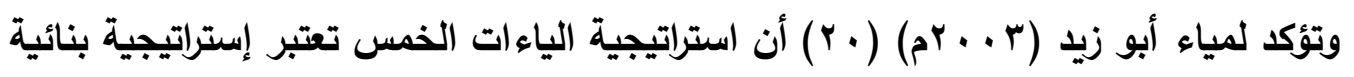

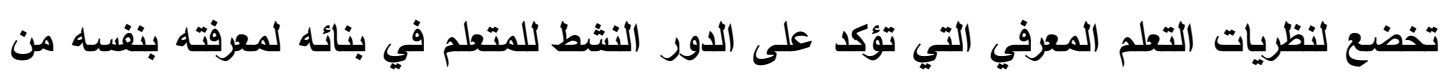

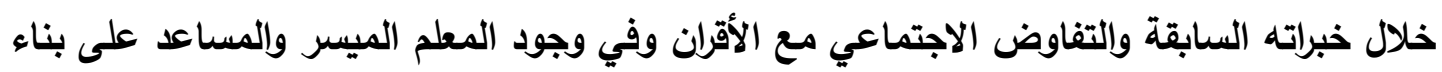
المعنى بصورة صحيحة من خلال النشاطات والتجارب والطرق التدريسية المختلفة.

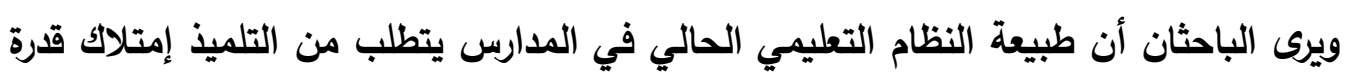

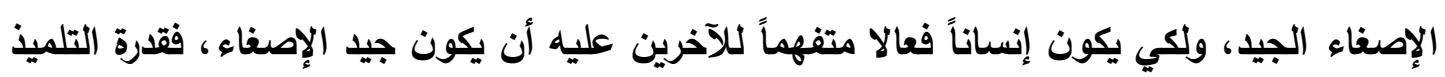

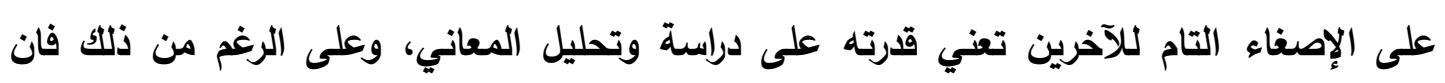

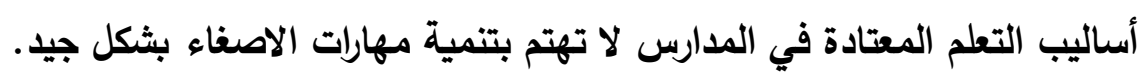

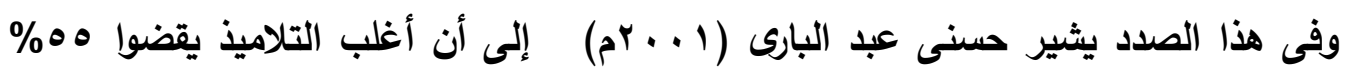

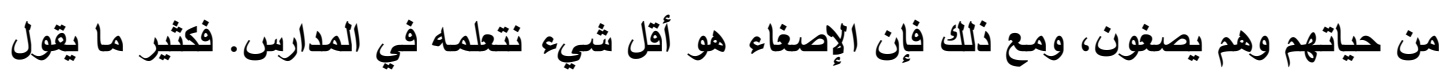

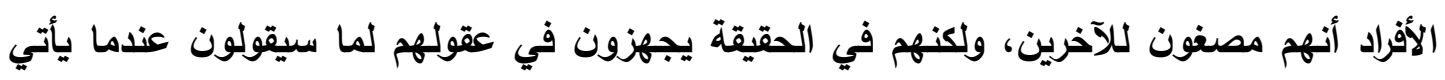

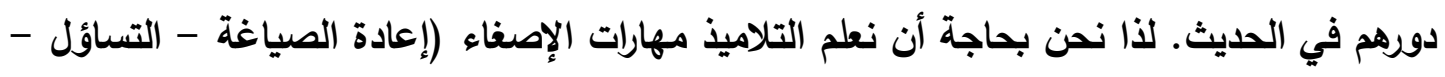

$$
\text { تنظيم أدوار المتكلم) (ب إ: ع V). }
$$

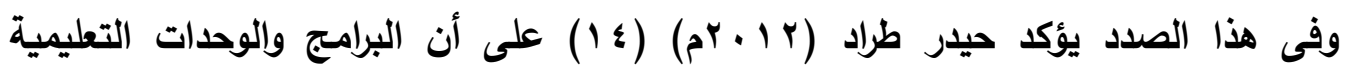
المتميزة تتضمن أنثطة تنمى عادات العقل وهي من الأساليب الحديثة المتبعة لتطوير التفكير التير 
تأثير استخدام إستراتيجية الياءات الخمس (5E's)على عادات العقل وتعلم بعض المهارات الحركية في الكرة

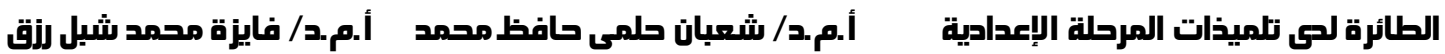

الابداعي. وتعطي الحرية للتلميذ في التفكير وطرح أفكاره وآرائه دون قيود أو حرج، ويولد لايه الرغبة

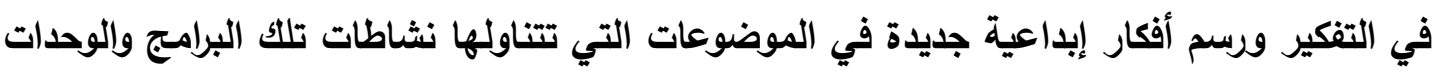

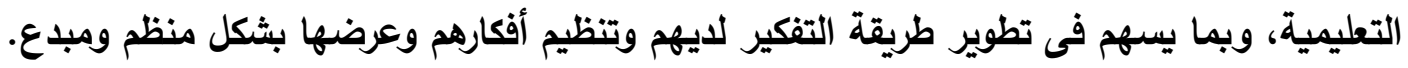
وهذا ما تم مراعاته عند تنفيذ الوحدة التعليمية باستخدام استراتيجية الياءات الخمس.

\section{- مناقشة|الفروض الرابع والخامس والسادسوتفسيرهم والذين ينصوا على :}

؛ - يوجد فرق دال إحصائياً عند مستوى (ه ...) بين متوسطى القياسين القبلي والبعدي للمجموعة

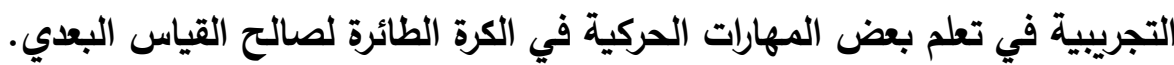
ه - يوجد فرق دال إحصائياً عند مستوى (ه ...) بين متوسطى القياسين القبلي والبعدي للمجموعة فئات

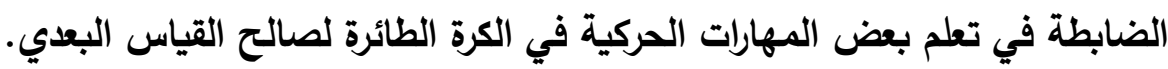

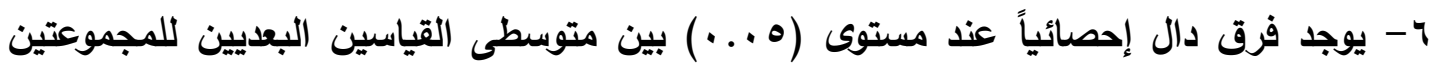

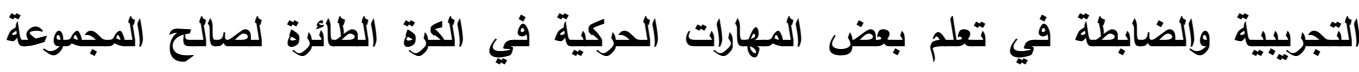
التجريبية.

يتضح من الجدول (r آ) وجود فروق ذات دلالة إحصائية بين القياسين القبلي والبعدي

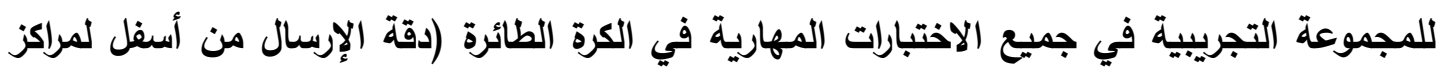

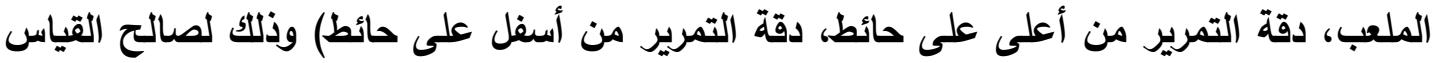

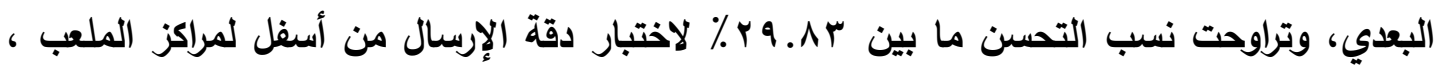

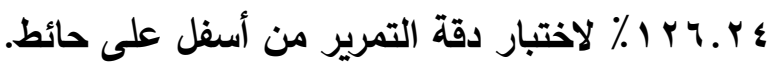
ويتضح من الجدول (ع ا) وجود فروق ذات دلالة إحصائية بين القياسين القبلي والبعدي

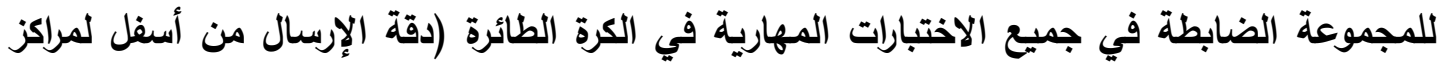

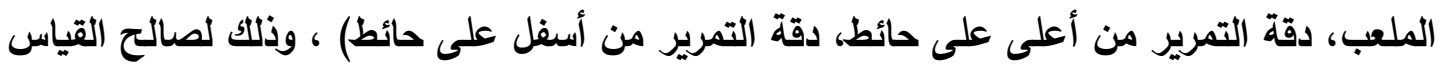

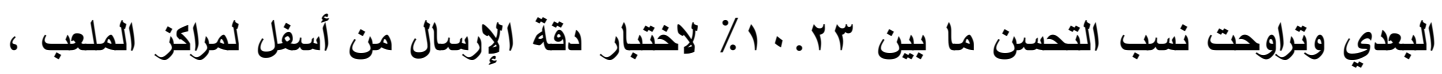
ه ؛ ـ 1 \% لاختبار دقة التمرير من أسفل على حائط.

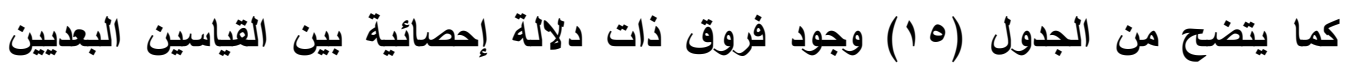

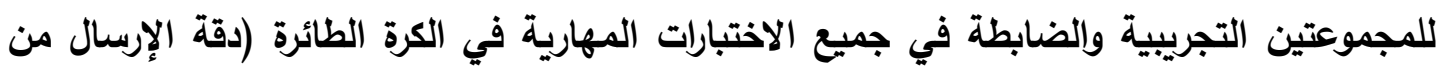

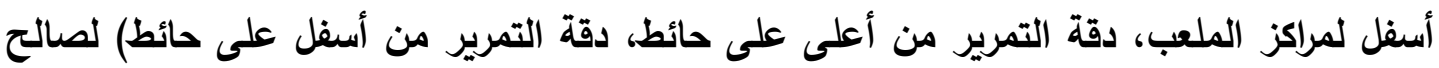
القياس البعدي للمجموعة التجريبية.

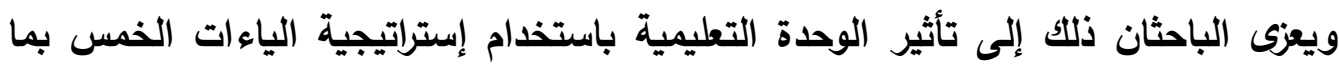

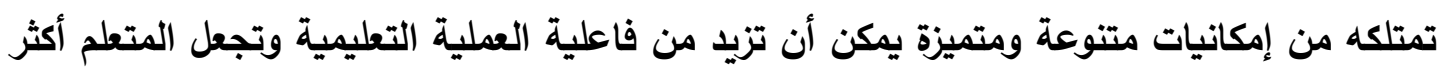
إيجابية وتحفزه على إكتساب المهارات المطلوبة. 
ويرى الباحثان أن تقدم تلميذات المجموعة التجريبية فى القياسات البعدية للمتغيرات المهارية

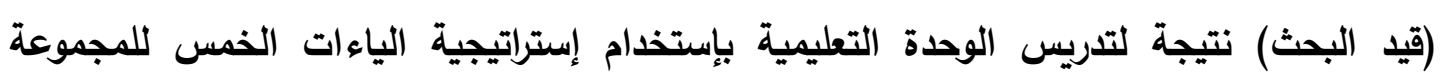

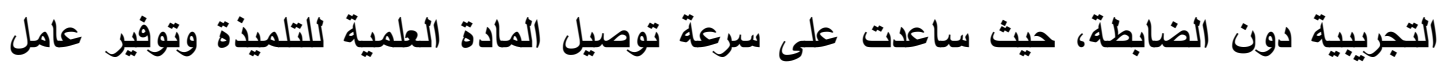
الإثارة والتثويق لهن أثناء عملية التعلم بصورة أفضل، بالإضافة إلى أن إلى إستخدام استراتيجية

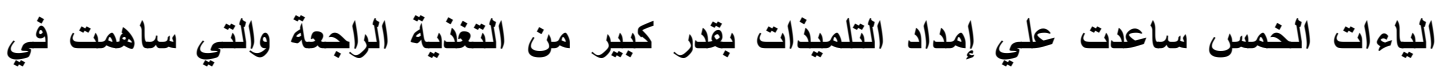

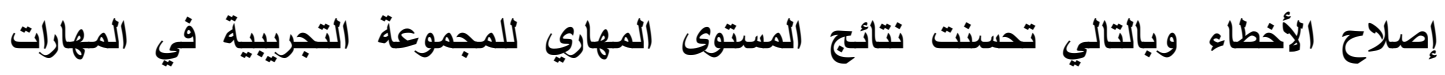

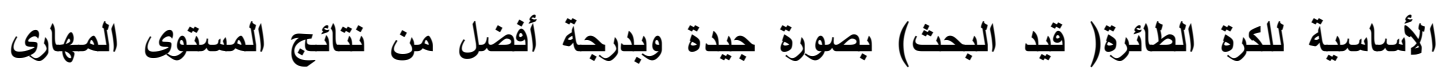
للمجموعة الضابطة.

كما أن الخطوات المتبعة في إستراتيجية الياءات الخمس ساعدات على تنظيم المعلومات

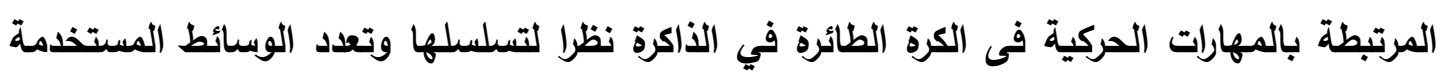
في المنظومة والتى أسهمت في عملية استيعاب المعلومات واستردادها عند الحاجة إليها أثناء الأداء.

وفى هذا الصدد يثير أمين الخولي ومحمود عذان (9991م) إلى أن دور المعلم في المجال

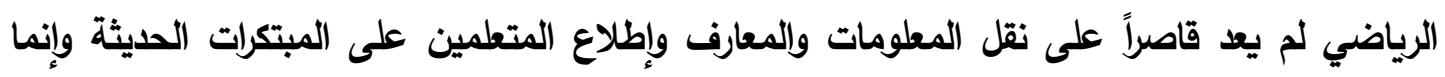

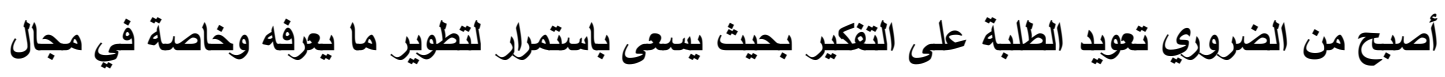

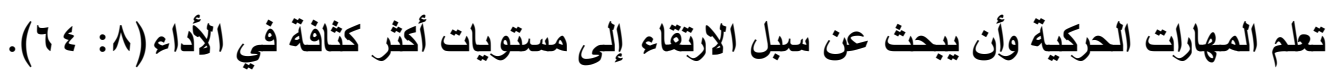

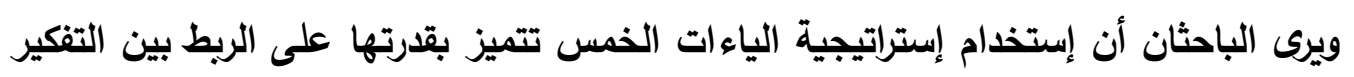

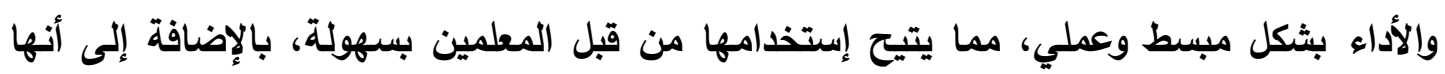
تمتاز بالتماسك بحيث تبقى سليمة على مدار انتقالها من المعلمة إلى التلميذة.

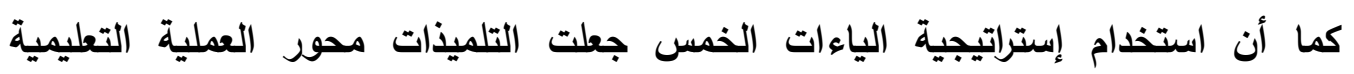

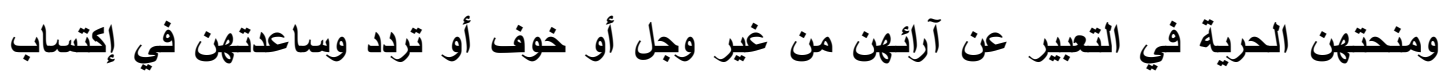

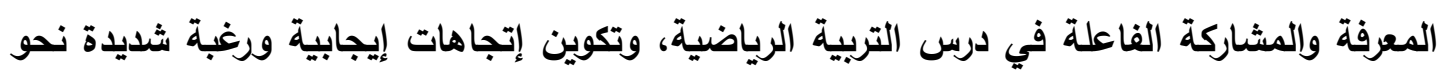

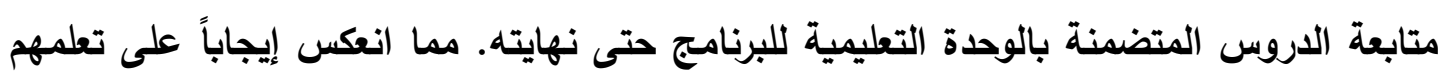

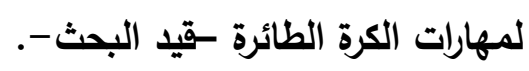

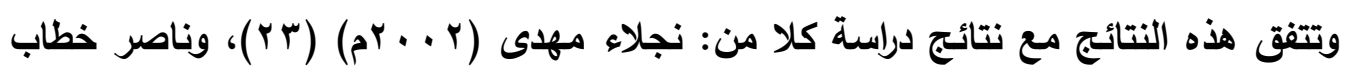

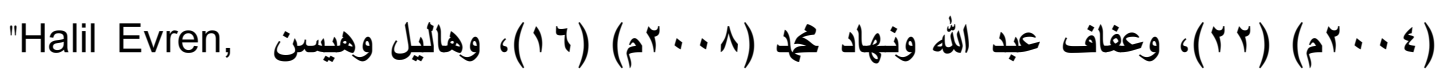

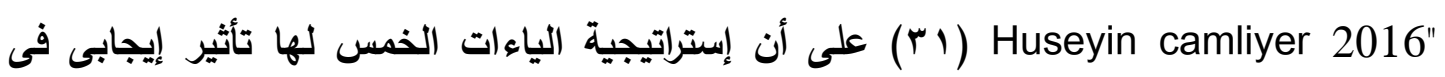
تنمية مهارات المتعلمين 
تأثير استخدام إستراتيجية الياءات الخمس (5E's)على عادات العقل وتعلم بعض المهارات الحركية في الكرة

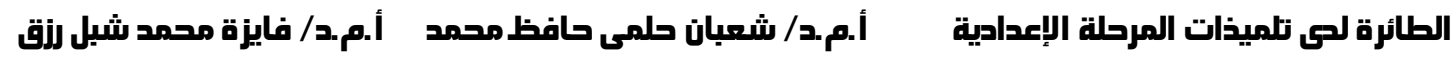

\section{الاستخلاصاتوالتوصيات: \\ أولاً: الاستخلاصات:}

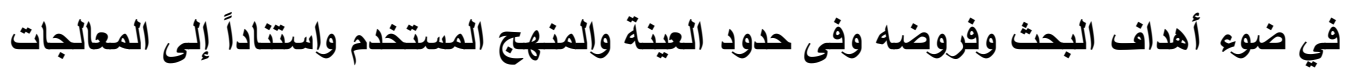

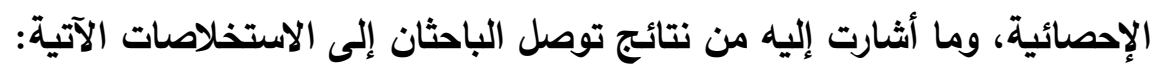

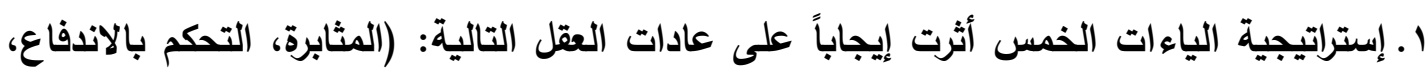

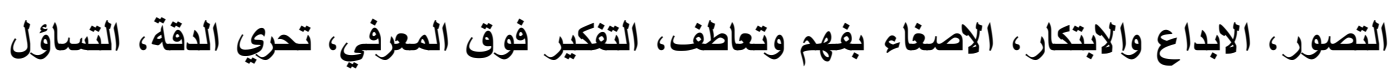

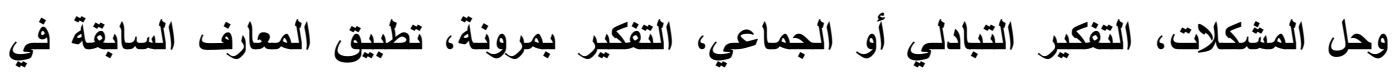

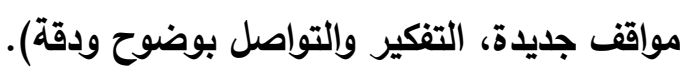
r. إستراتيجية الياءات الخمس أثرت إيجاباً على المهارات الحركية التالية في رياضة التهائ الكرة الطائرة (دقة الإرسال من أسفل لمراكز الملع، دقة التمرير من أعلى على حائط، دقة التمرير من أسفل على حائط). r. يوجد معدل تغير فى المجموعتين التجريبية والضابطة فى عادات العقل التالية: (المثابرة، التحكم

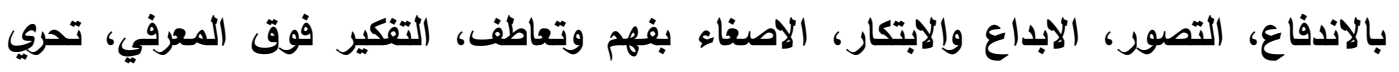

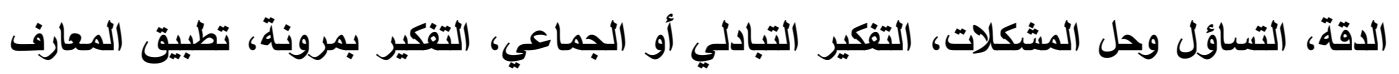

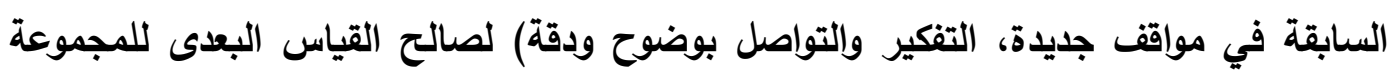

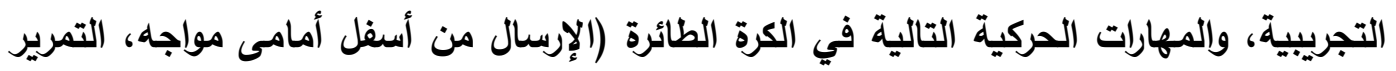

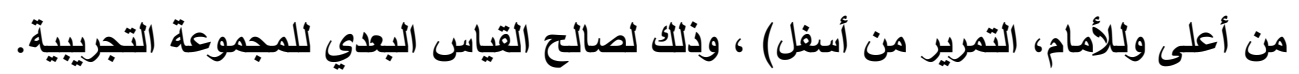
ثانياً: التوصيات: اعلى ولاتما: في ضوء أهداف البحث وإجراءاته وفى حدود عينة البحث واستناداً إلى ما توصل إليه الباحثان من نتائج خلال دراستهما يوصيا بما يلي:

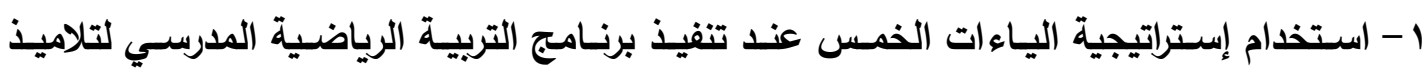
المرحلة الإعدادية لما له من تأثير إيجابي على جوانب البداءت نموهم المختلفة.

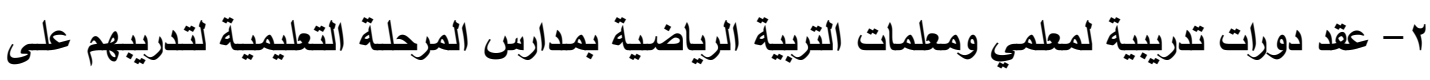
استخدام إستراتيجية الياءات الخمس في تدريسهم بدرس التربية التربية الرياضية.

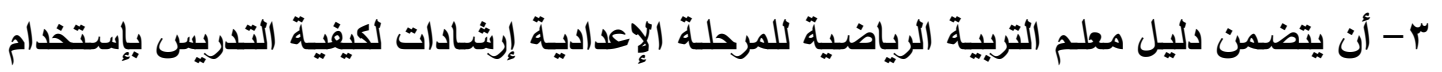

$$
\text { إستراتيجية الياءات الخمس. }
$$

؛ - إجراء دراسات مشابهة عند استخدام إستراتيجية الياءات الخمس في تدريس التربية الرياضية

$$
\text { بمراحل التعليم المختلفة وفي أنثطة رياضية أخرى. }
$$

ه - الاعتماد على التعلم البنائي في تدريس التربية الرياضية بمراحل التعليم المختلفة وعدم الاقتصار التبار

$$
\text { على استخدام الاساليب التقليدية. }
$$


ا- إبراهيم أحمد الحارثي (r . . rم): العادات العقلية وتتميتها لدى التلاميذ، مكتبة

$$
\text { الشفري، الرياض. }
$$

ץ-احمد حسين اللقاني (099 (9): المنهج (الأسس، المكونات، التنظيمات)، دار عالم

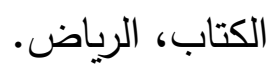

r- آرثر كوستا، وبينا كاليك(r . r م): استكثاف وتقصي عادات العقل ترجمة مدارس الظهران، دار الكتاب التربوي للنشر والتوزيع، الرياض.

ع - أسماء عطا الله محمود (r I • r م): فعالية برنامج تدريبي في تتمية بعض عادات العقل لدى تلاميذ المرحلة الإعدادية بقنا، دراسة ماجستير، كلية التربية بقنا،

$$
\text { جامعة جنوب الوادى. }
$$

ه-أصلان صبح المساعيد (11 + r م) : مستويات عادات العقل عند طلبة الصف العاشر في ضوء متغير الجنس، مجلة جامعة الشارقة للعلوم الإنسانية

$$
\text { والاجتماعية المجلد (^) ، العدد (ب). }
$$

צ- أمل طعمه ورند العظمة(r . . . م): برنامج هندسة التفكير ، وزارة الإعلام، دمشق.

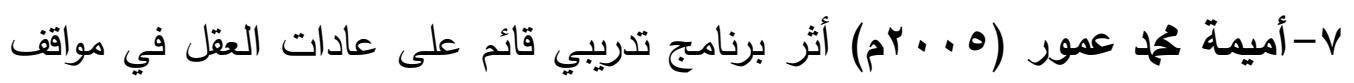
حياتية في تتمية مهارات التفكير الابداعي لدى طلبة المرحلة الأساسية، رسالة

$$
\text { دكتوراة، جامعة عمان العربية للاراسات العليا، عمان. }
$$

1- أمين أنور الخولي ومحمود عبد الفتاح عنان(999 ام): المعرفة الرياضية، دار

$$
\text { الفكر العربي، القاهرة. }
$$

9- إيمان صابر العزب (Y I • r P) : وحدة مقترحة لتتمية بعض عادات العقل لدى طلاب الشعب العلمية بكلية التربية جامعة بنها، رسالة دكتوراه، كلية التربية،

جامعة بنها.

• 1 - بهيرة شفيق إبراهيم (0 ( • rم): استراتيجيات حديثة فى التدري، دار العالم

العربى، القاهرة.

1 - حسن زيتون وكمال زيتون (Y 9 (9 م): البنائية منظور ابتسمولوجي وتربوي، منشاة

المعارف، الإسكندرية. 


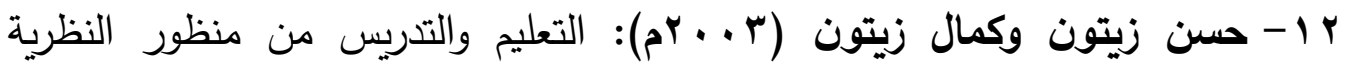
البنائية، عالم الكتب، القاهرة.

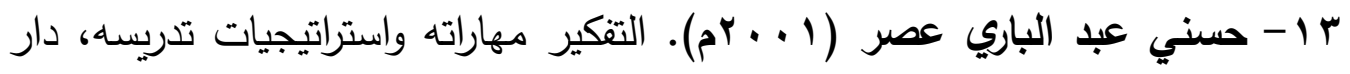
الوفاء الإسكندرية.

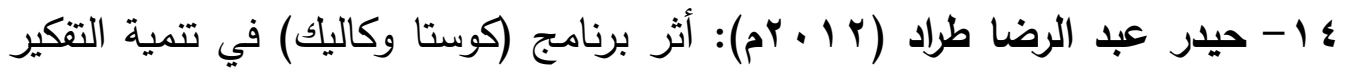

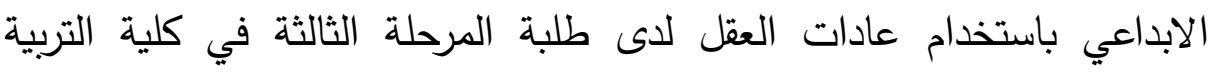
الرياضية، مجلة علوم التربية الرياضية، العدد الأول، المجلد الخامس، العراق.

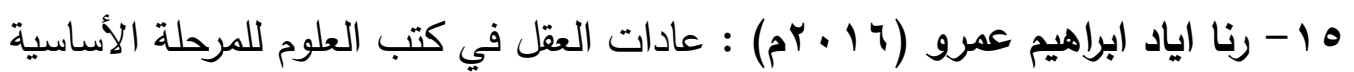

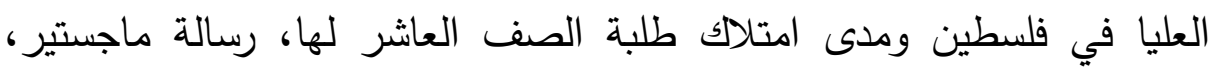
جامعة القدس، فلسطين. 17 - 14

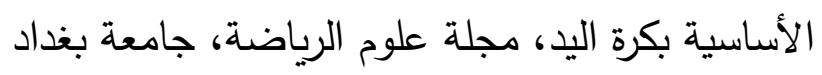

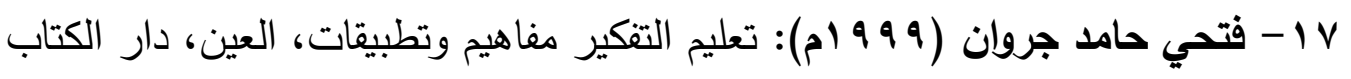

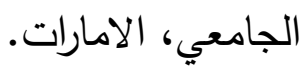
11 - فتحية صبحي اللولو (11 + rم): أثر توظيف نموذج الخطوات الخمس البنائي في تتمية مهارات التحليل والتركيب والعلوم لاى طالبات الصف التاسع بغزة، كلية التربية، الجامعة الإسلامية، غزة.

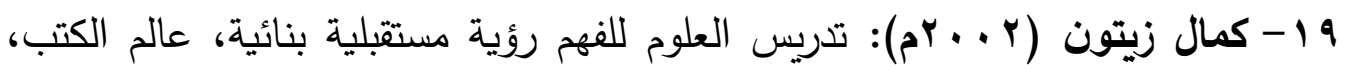

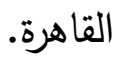

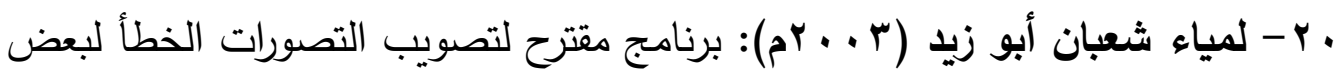

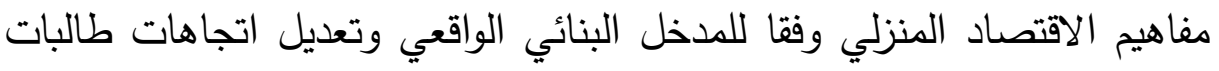

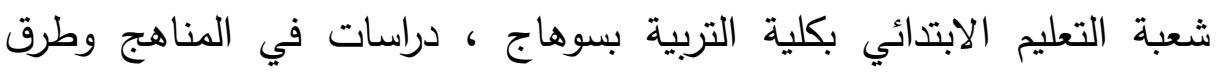

$$
\text { التدريس، العدد (• (9). }
$$

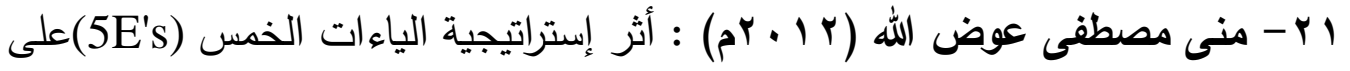

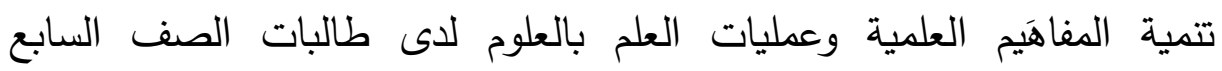
الأساسي بغزة، رسالة ماجستير ، كلية التربية، الجامعة الإسلامية بغزة، فلسطين. 


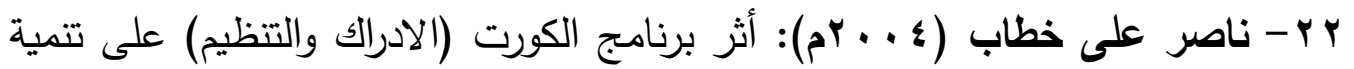

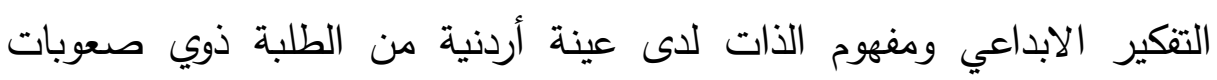

$$
\text { التعلم. رسالة دكتوراه، الجامعة الأردنية. }
$$

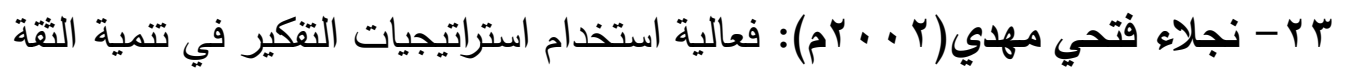

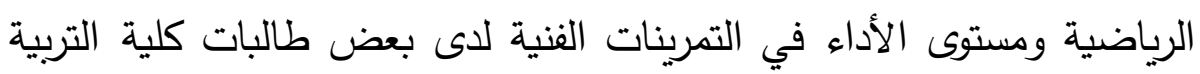

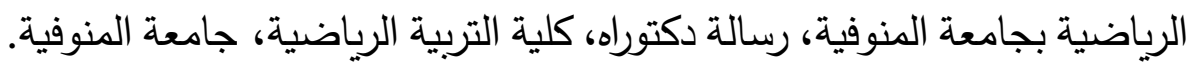

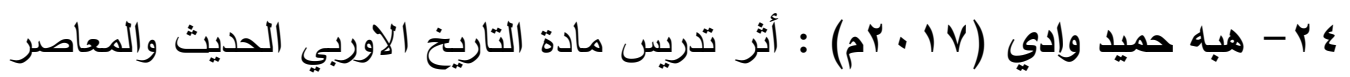

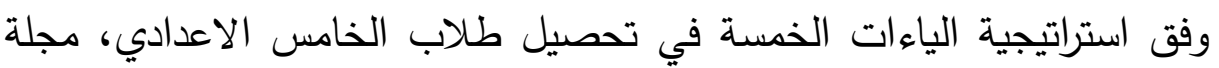

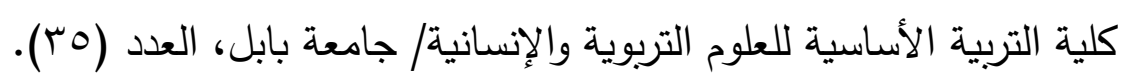

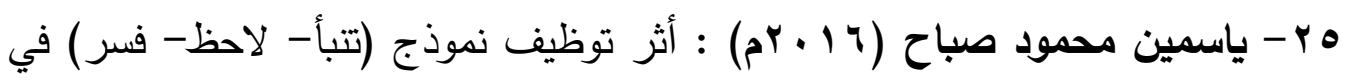

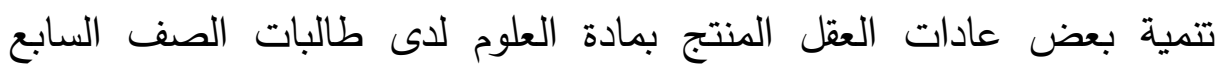

الأساسي، رسالة ماجستير ، كلية التربية، الجامعة الإسلامية بغزة، فلسطين.

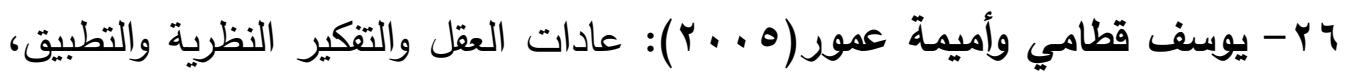

$$
\text { دار الفكر، عمان. }
$$

ثانيا-المراجع الأجنبية:

27- Costa, A. \& Kallick, B. (eds) (2004): Discovering and Exploring Habits of Mind, Hawker Brownlow Education, Heatherton, Melbourne.

28- Costa, A. L. (2000). Components of a well -developed thinking skills program. Seattle, WA: New Horizons. www.newhorizons.org/strategies/thinking/costa2.htm

29- Costa. A. L. \& Kallick, B. (2001): Habits of mind. Highlands Ranch, CO: Search Models Unlimited. www.habits-ofmind.net

30- Febrianto Putra, Ika Yunita Nurkholifah, Ani Rusilowati, Bambang Subali (2018). 5E-learning cycle strategy: increasing conceptual understanding and learning motivation, Jurnal Ilmiah Pendidikan Fisika Al-BiRuNi 07 (2), 171-181

31- Halil Evren Senturk, Huseyin Camliyer (2016). A New Learning Model on Physical Education: 5ELearning Cycle, Universal Journal of Educational Research 4(1): 26-29

32- Marzano, R., Pickering, D. \& Pollock, J. (2001): Classroom Instruction That Works, Association for Supervision and 
تأثير استخدام إستراتيجية الياءات الخمس (5E's)على عادات العقل وتعلم بعض المهارات الحركية في الكرة

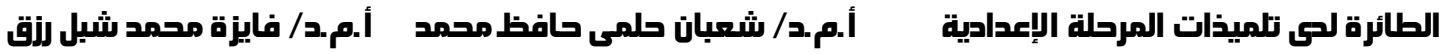

Curriculum Development, Association for Supervision and Curriculum Development, Alexandria, Virginia.

33- Ritchhart, R., Church, M. \& Morrison, K. (2011): Making Thinking Visible: how to promote engagement, understanding, and independence for all learners, John Wiley \& Sons, Stafford, Queensland.

34- Wegerif, R. (2002): Literature review in thinking skills, technology, and learning. Bristol, England: NESTA. www.nestafuturelab.org/research/reviews/ts01.htm

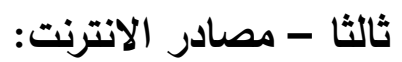

35- http://forum.moe.gov.om/ moeoman/vb/showthread.php?t=5114 $\underline{81}$

36- http://neweducators-hananradwan.blogspot.com/2013/06/habitsof-mind.html

37- http://www.bareedmm.com/index.php?option=com_content\&vie $\mathrm{w}=$ article \&id=53:-- $61 \&$ catid $=37: 2010-03-12-06-30-$

$04 \&$ Itemid $=72$ 


\section{مستخلص البحث}

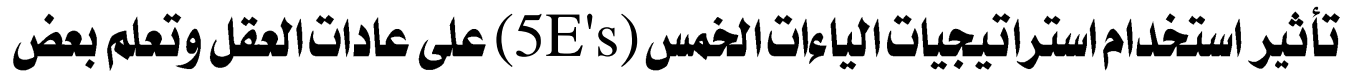 المهاراتالحركية في الكرة الطائرة للدى طالبات المرحلة الإعلدادية}

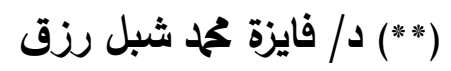

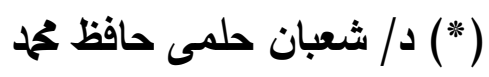

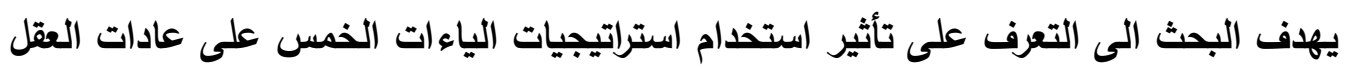

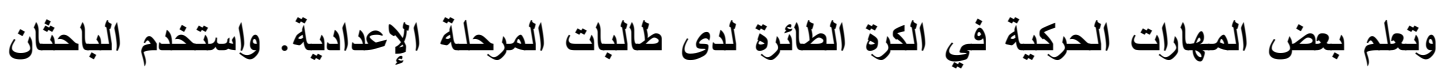

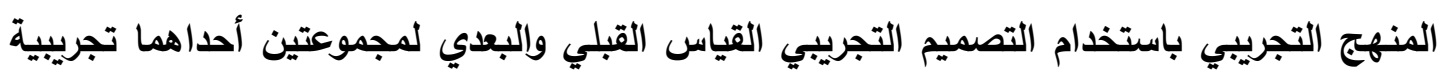

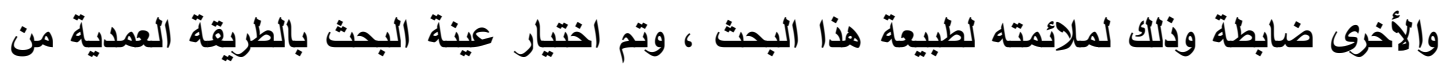

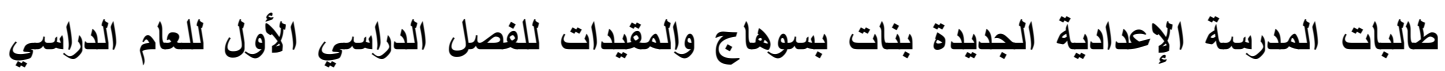

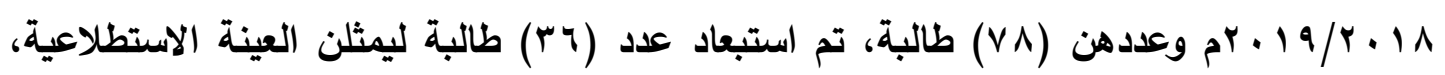

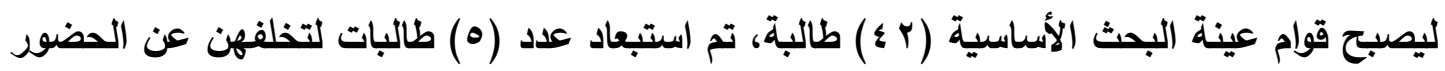

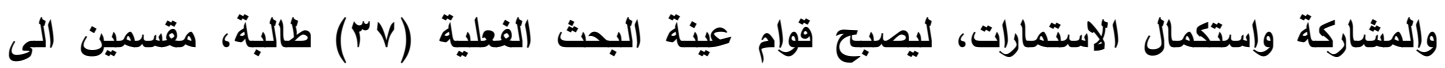

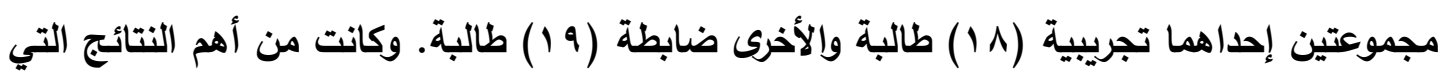

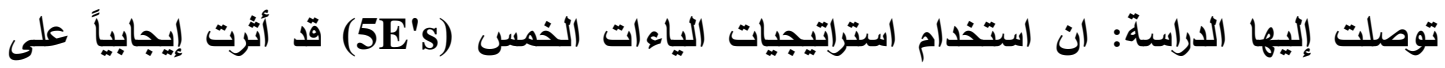

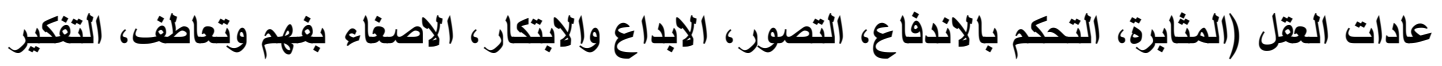

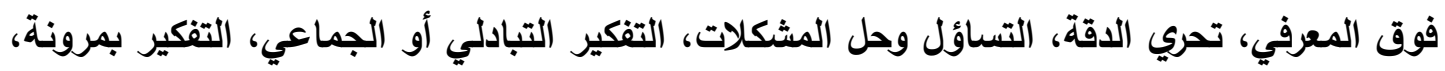

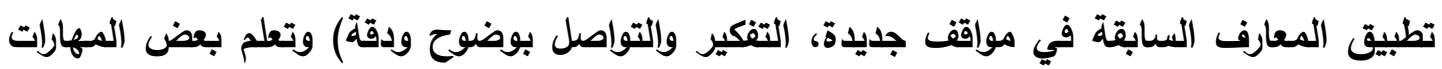

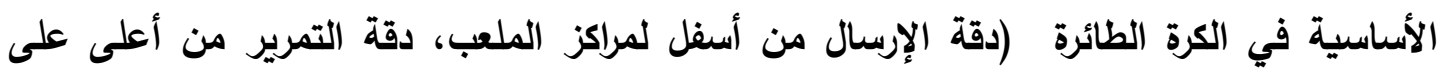
حائط، دقة التمرير من أسفل على حائط) لاى طالبات المجموعة التجريبية. 
تأثير استخدام إستراتيجية الياءات الخمس (5E's)على عادات العقل وتعلم بعذ المهارات الحركية في الكرة

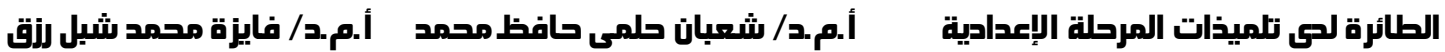

\section{Abstract}

\section{Effect of 5E strategies on mind habits and learning of certain} basic skills for in volleyball female preparatory students

(*)Dr. Shaban Helmy Hafiz Muhammad

(**) Dr. Fayza Muhammad Shebl Rizk

The research aims to identify the impact of the use of the $5 e$ strategies on habits of the mind and learn certain basic skills in volleyball among prep students. the researchers used the experimental method using the experimental design pre and post measurements for two groups, one experimental and the other control, due to its relevance to the nature of this research. (36) female preparatory students represent the exploratory sample, so that the strength of the basic research sample is (42) students, (5) students were excluded because they failed to attend and participate and complete the forms, so that the strength of the actual research sample becomes (37) students, divided into two groups one of them a pilot (18) female students and the other female (19) female students. the most important findings of the study: using the 5e's strategies has positively impacted of mind habits (perseverance, impulsivity control, perception, creativity and innovation, listening with understanding and sympathy, supra-cognitive thinking, investigation of accuracy, questioning problem solving, reciprocal or group thinking, thinking with flexibility, applying previous knowledge in new situations, thinking and communicating clearly and accurately) and learning some basic skills in volleyball (accuracy of transmission from bottom to center of the field, accuracy of passing from top to wall, accuracy of passing from bottom on wall) to experimental group. 